\title{
Does Mandatory IFRS Adoption Improve the Information Environment?
}

\section{Citation}

Horton, Joanne, George Serafeim, and loanna Serafeim. "Does Mandatory IFRS Adoption Improve the Information Environment?" Contemporary Accounting Research (forthcoming).

\section{Permanent link}

http://nrs.harvard.edu/urn-3:HUL.InstRepos:9887632

\section{Terms of Use}

This article was downloaded from Harvard University's DASH repository, and is made available under the terms and conditions applicable to Open Access Policy Articles, as set forth at http:// nrs.harvard.edu/urn-3:HUL.InstRepos:dash.current.terms-of-use\#OAP

\section{Share Your Story}

The Harvard community has made this article openly available.

Please share how this access benefits you. Submit a story.

\section{Accessibility}




\title{
DOES MANDATORY IFRS ADOPTION IMPROVE THE INFORMATION ENVIRONMENT?
}

\author{
Joanne Horton ${ }^{*}$, George Serafeim ${ }^{\S}$ and Ioanna Serafeim ${ }^{\alpha}$
}

\begin{abstract}
More than 120 countries require or permit the use of International Financial Reporting Standards ('IFRS') by publicly listed companies on the basis of higher information quality and accounting comparability from IFRS application. However, the empirical evidence about these presumed benefits are often conflicting and fail to separate between information quality and comparability. In this paper we examine the effect of mandatory IFRS adoption on firms' information environment. We find that after mandatory IFRS adoption consensus forecast errors decrease for firms that mandatorily adopt IFRS relative to forecast errors of other firms. We also find decreasing forecast errors for voluntary adopters, but this effect is smaller and not robust.

Moreover, we show that the magnitude of the forecast errors decrease is associated with the firmspecific differences between local GAAP and IFRS. This finding suggests that it is IFRS adoption rather than a correlated unobservable factor that is causing forecast errors to decrease. Exploiting individual analyst level data and isolating settings where analysts would benefit more from either increased comparability or higher quality information, we document that the improvement in the information environment is driven both by information and comparability effects. These results suggest that mandatory IFRS adoption has improved the quality of information intermediation in capital markets and as a result firms' information environment by increasing both information quality and accounting comparability.
\end{abstract}

JEL Classification: M41, G14, G15

Keywords: IFRS, analysts, information environment, comparability, accounting quality

\footnotetext{
*University of Exeter, email: j.horton@exeter.ac.uk

${ }^{\S}$ Harvard Business School, email: gserafeim@ @bs.edu (corresponding author)

${ }^{\infty}$ Capital Market Commission (Greece), email: i.serafim@cmc.gov.gr

We are grateful to Hollis Ashbaugh-Skaife, Wayne Landsman, Christian Leuz, Richard Macve, Theodore Sougiannis, Martin Walker and seminar participants at the $3^{\text {rd }}$ MAFG/LSE/MBS Conference: The Challenges of Global Financial Reporting and London School of Economics for many helpful comments.
} 


\section{Introduction}

According to proponents of International Financial Reporting Standards (IFRS) publicly traded companies must apply a single set of high quality accounting standards in order to contribute to better functioning capital markets (Quigley 2007). Therefore, mandatory IFRS adoption has the potential to facilitate cross-border comparability, increase reporting transparency, decrease information costs, reduce information asymmetry, and thereby increase the liquidity, competitiveness, and efficiency of markets (Ball 2006; Choi and Meek 2005).

These potential benefits rely on the presumption that mandatory IFRS adoption provides superior information to market participants and/or increased accounting comparability compared to previous accounting regimes. However, there is little and often conflicting empirical evidence that this is the case. Moreover, while all of these potential benefits provide a persuasive argument for IFRS adoption, the costs associated with such a transition cannot be ignored. For example, Ball (2006) notes that the fair value orientation of IFRS could add volatility to financial statements. This volatility takes the form of both good and bad information; the latter consisting of noise that arises from inherent estimation error and possible managerial manipulation.

Whether harmonization will actually be achieved is also currently up for debate with many commentators arguing that the same accounting standards can be implemented differently (Kvaal and Nobes 2010; Schipper 2005). In the absence of suitable enforcement mechanisms, real convergence and harmonisation is unlikely to happen (Ball 2006). Cultural, political, and business differences might continue to impose significant obstacles in the progress towards this single global financial communication system (Armstrong, Barth, Jagolinzer, and Riedl 2010; Soderstrom and Sun 2007) and incentives might continue to dominate the potential effects of accounting standards (Bradshaw and Miller 2007; Lang, Raedy, and Wilson 2006). Notwithstanding high quality standards, there is still a risk of having relatively low quality 
accounting numbers when firms have incentives and opportunities to manipulate their financial statements (Leuz 2003).

In this paper, we investigate which attributes of IFRS cause an improvement in the information environment of firms. Prior and contemporaneous studies investigating the impact of IFRS on analysts' forecasting ability have generally found that analyst forecast errors significantly reduced following voluntary adoption of IFRS (Ashbaugh and Pincus 2001; Ernstberger, Krotter, and Stadler 2008; Hodgdon, Tondkar, Harless, and Adhikari 2008; Bae, Tan, and Welker 2008) and for certain groups under mandatory adoption of IFRS (Wang, Young, and Zhuang 2008; Byard, Li, and Yu 2011; Preiato, Brown, and Tarca 2009; Cotter, Tarca, and Wee 2010; Tan, Wang, and Welker 2009; Glaum, Baetge, Grothe, and Oberdoerster 2011). However, it is difficult to establish from these results the actual causes for such improvements. The question arises: what is it about IFRS adoption that leads to an increase in forecast accuracy? In this paper, we test whether the increase in forecast accuracy can be attributed to higher quality information and/or greater comparability from IFRS adoption, or simply that IFRS gives managers greater opportunities to manipulate their earnings and hence meet analysts' forecasts.

We find that after mandatory IFRS adoption forecast accuracy and other measures of the quality of the information environment increase significantly more for mandatory adopters relative to non-adopters and voluntary adopters. Unlike prior studies, we do not find that voluntary adopters benefit significantly more from mandating IFRS compared to mandatory adopters (Daske, Hail, Leuz, and Verdi 2008). To isolate the effect of mandatory adoption we control for time-varying and persistent unobservable firm characteristics that affect forecast accuracy. We also control for industry-year and country-year effects to mitigate any industry and countrywide changes in forecast accuracy. The results are robust to alternative dependent variables, alternative samples of control firms, and forecast horizon choices. 
We also hold constant any information effects from IFRS adoption and find that the increase in forecast accuracy is partly driven by comparability benefits. We establish this result by analysing three groups of analysts. First, analysts covering firms that report under a single local GAAP before mandatory adoption (for example all firms report under UK GAAP), but after mandatory adoption some firms switch to IFRS while other firms continue to report under local GAAP. For these analysts, we expect accounting comparability to decrease. Second, analysts covering firms that report under a single local GAAP before mandatory adoption and after mandatory adoption all firms switch to IFRS. For these analysts, we expect accounting comparability to remain the same. Third, analysts covering firms that report under multiple local GAAP before mandatory adoption (for example some firms use UK GAAP and other firms use Spanish GAAP), but after mandatory adoption all firms switch to IFRS. For these analysts, we expect accounting comparability to increase. We expect that, if information effects exist for mandatory adopters, all three groups of analysts are going to benefit. To eliminate the possibility that an analyst's choice to change firm coverage affects the results, we include in the analysis only mandatory adopters that the analyst is covering both before and after mandatory adoption.

Consistent with the presence of a comparability benefit from IFRS adoption, forecast accuracy improves more for analysts with portfolios that move from Local GAAP to IFRS compared to Local GAAP to Multiple GAAP. Moreover, this effect is even greater for analysts with portfolios that move from Multiple GAAP to IFRS.

Furthermore, we hold constant any comparability effects from IFRS adoption and find that the increase in forecast accuracy is partly driven by information benefits. We consider analysts covering firms that report under multiple local GAAP before mandatory adoption and after mandatory adoption all the firms covered switch to IFRS. From the portfolios of those analysts, we select voluntary and mandatory adopters that these analysts cover both before and after mandatory adoption. We expect that if IFRS increases information quality then forecast 
accuracy should improve more for mandatory than for voluntary adopters. We assume that for these analysts comparability effects will be present for both mandatory and voluntary adopters. We find results consistent with this information quality effect. For this set of analyst-firm pairs forecast accuracy improves more for mandatory adopters.

In addition, we find that forecast accuracy improves more for firms with accounting treatments that differ the most from IFRS. This finding provides some confidence that it is IFRS adoption that causes this change in forecast accuracy rather than a correlated omitted variable. We interpret this result as being consistent with those firms with the largest deviation of accounting practices from IFRS prior to mandatory adoption benefiting more from comparability and information benefits (Horton and Serafeim 2010; Beuselinck, Joos, and Van der Meulen 2010; Brochet, Jagolinzer, and Riedl 2011).

However, an alternative explanation of this result is that the reconciliation component captures the increased opportunities for managers to use the additional accruals adjustments allowed under IFRS to manipulate their earnings in order to meet or beat analysts' forecasts. We do not find evidence consistent with this explanation. Moreover, when we consider whether the increase in forecast accuracy is driven primarily by mandatory adopters with more opportunities to manipulate their earnings, such as firms with larger accruals or firms that analysts do not forecast cash flows, we do not find any evidence in support of this claim.

We make a number of contributions to the existing literature. First, our study contributes to the literature on the consequences of disclosure by examining the effect of mandatory IFRS adoption on analysts (Ashbaugh and Pincus 2001; Wang et al. 2008; Tan et al. 2009) and on the information environment (Lang, Lins, and Miller 2003). We also add to the previous literature by documenting a larger improvement in the information environment for mandatory adopters relative to voluntary adopters and non-adopters (Daske et al. 2008) and find that this improvement is associated with the firm's earnings reconciliation adjustment. 
Second, by providing evidence that the increase in forecast accuracy appears to be driven both by information and comparability effects, we contribute to the growing body of literature that directly investigates the comparability benefits (Bielstein, Munter, and Schinas 2007; Daske et al. 2008; DeFond, Hu, Hung, and Li 2011) and information benefits of IFRS (Ashbaugh and Pincus 2001; Barth, Landsman, and Lang 2008; Horton and Serafeim 2010). Finally, by offering evidence that the increase in forecast accuracy appears not driven by manipulation, we also contribute to the debate on the role of incentives and whether managers exercise their judgement opportunistically when implementing IFRS (Leuz 2003; Ball, Robin, and Wu 2003; Christensen, Lee, and Walker 2009; Chen, Tang, Jiang, and Lin 2010).

The remainder of the paper is organized as follows. Section 2 reviews the literature and presents the hypotheses. Section 3 describes the research design. Section 4 presents the sample selection process and summary statistics. Section 5 presents the results and section 6 concludes.

\section{Literature review and motivation}

\section{Background: IFRS adoption}

Countries with prominent capital markets, such as Australia, European Union (EU) members, Hong Kong, Philippines, and South Africa, require publicly traded companies (with certain exceptions) to present consolidated financial statements in conformity with IFRS for each financial year starting on or after January 1, 2005. Other countries, such as Japan, have decided to adopt IFRS in the future and already allow companies to voluntarily report under IFRS.

While mandatory adoption of IFRS was widespread in 2005, there are still firms that follow other accounting standards. In countries such as the United States, Mexico, China, Malaysia, and Brazil, firms were not allowed to use IFRS. In other countries, certain firms were exempt from IFRS adoption. For example, in the United Kingdom, companies listed in the Alternative Investment Market (AIM) were not subject to the EU International Accounting 
Standards (IAS) Regulation. The AIM had adopted a rule that required AIM firms to submit financial statements prepared using IFRS for periods beginning on or after January 1, 2007, although voluntary adoption was allowed. Swiss firms that are not multinationals are also exempt from IFRS compliance. ${ }^{1}$ These companies may continue to use Swiss GAAP, or they may choose IFRS or U.S. GAAP. In addition, the IAS Regulation is only applicable to consolidated accounts and many investment trusts that only publish parent accounts are by their very nature exempt. Companies reporting under IFRS can be split into voluntary and mandatory adopters. The first group includes all companies that adopted IFRS before 2005, while the latter group consists of firms that were forced to adopt IFRS. As a result, there are three distinct groups of firms: (i) 'nonIFRS adopters' that exploit the exemptions and choose not to report under IFRS or that are listed in countries where IFRS is not allowed; (ii) 'mandatory adopters' that only adopt when they are forced to comply; and (iii) 'voluntary adopters' that choose to comply with IFRS in the period before the regulatory rules demanded IFRS adoption.

Although earlier studies on 'voluntary adopters' provide valuable evidence about the effects of IFRS adoption, these results may not be generalizable in the current mandatory setting (Daske et al. 2008; Horton and Serafeim 2010). We expect any effects from IFRS mandatory adoption to be different from those documented for voluntary IFRS adopters (Ashbaugh and Pincus 2001; Bae et al. 2008; Guan, Hope, and Kang 2006) since the former group is essentially forced to adopt IFRS compared to the latter that chooses to adopt. For example, past research finds that the decision to voluntarily adopt IFRS reporting is only one element of a broader strategy that increases a firm's overall commitment to transparency (Daske et al. 2008; Leuz and Verrecchia 2000). Therefore, any effects around voluntary IFRS adoptions cannot be attributed solely to IFRS

\footnotetext{
${ }^{1}$ Switzerland is not a member of the EU and therefore is not subject to the EU IAS Regulation. The Swiss Foundation for Accounting and Reporting publishes accounting standards. Compliance with Swiss GAAP is required for all companies, however compliance with IFRS ensures compliance with Swiss GAAP and many large Swiss companies have, for a number of years, followed IASs/IFRS. However, starting with annual reports for 2005 and interim reports for 2006, most Swiss companies whose equity shares are listed on the main board of the Swiss Exchange were required to prepare their financial statements using either IFRS or U.S. GAAP.
} 
compliance. Moreover, in a mandatory setting, firms are more likely to be affected by reporting externalities; for example, disclosure by one firm being useful in valuing other firms through intraindustry information transfers. In contrast, in a voluntary setting there are fewer firms disclosing and therefore such externalities may be moderate.

\section{Information environment and research analysts}

Our approach follows prior research ${ }^{2}$ that uses the characteristics of analyst forecasts as a proxy for the information environment. In particular, we focus on the accuracy of analyst forecasts. Previous studies suggest that more accurate forecasts indicate a firm with a better information environment. Lang and Lundholm (1996) find that firms with better disclosure have lower analyst forecast errors. Hope (2003) finds that countries with better disclosure policies and enforcement have higher analyst forecast accuracy. Similarly, we view changes in forecast errors as indicative of changes in a firm's information environment.

\section{Analyst forecasts and IFRS}

The studies investigating the effects of voluntary adoption of IFRS find an improvement in the information environment of analysts (Ashbaugh and Pincus 2001; Ernstberger et al. 2008; Hodgdon et al. 2008; Bae et al. 2008). In contrast, recent studies investigating the effect of mandatory IFRS adoption on the accuracy of analysts' forecasts have produced inconclusive results. The overall findings suggest improvements in forecast accuracy for some European and Australian firms after IFRS adoption (Wang et al. 2008; Byard et al. 2011; Preiato et al. 2009; Cotter et al. 2010; Tan et al. 2009). Byard et al. (2011) find an increase in the forecast accuracy, but only for those firms that were domiciled in countries with both strong enforcement regimes and domestic accounting standards that differed significantly from IFRS. Tan et al. (2009) find

\footnotetext{
2 See for example Lang and Lundholm (1996), Healy et al. (1999), Gebhardt, Lee, and Swaminathan (2001) and Lang et al. (2003).
} 
that forecast accuracy improves post-IFRS for foreign analysts, but not for domestic analysts. However, both Cotter et al. (2010) and Tan et al. (2009) find no evidence that the change in accuracy is increasing in the number of accounting differences between the firm's home GAAP and IFRS. ${ }^{3}$ Glaum et al. (2011) find that although the quality of disclosure improves after IFRS adoption, this finding explains only a small proportion of the overall improvement in forecast accuracy. While it is unclear exactly which attributes of IFRS reporting are driving this increase in analysts' forecast accuracy, the two most frequently claimed benefits associated with IFRS adoption are (i) an increase in accounting comparability and (ii) an increase in information quality.

\section{Comparability benefits}

A major potential benefit from the global move towards IFRS is an increase in accounting comparability. However, many commentators question the potential for IFRS to increase comparability because the same accounting standards can be implemented differently and in the absence of suitable enforcement mechanisms real convergence and harmonization is unlikely (Ball 2006).

Prior research has shown that as a firm's GAAP moves closer to foreign investors' or analysts' home GAAP this reduces investors' home bias (Bradshaw, Bushee, and Miller 2004; Covrig, DeFond, and Hung 2007; Yu 2010) and improves the efficiency of information intermediaries (Bae et al. 2008; Bradshaw, Miller, and Serafeim 2010). Tan et al. (2009) find that after mandatory IFRS adoption foreign analysts' following increases significantly more for those firms who had the greatest level of GAAP divergence. Yu (2010) finds mandatory IFRS adoption increases cross-border equity holdings for those firms where the divergence was greatest prior to IFRS.

\footnotetext{
${ }^{3}$ With respect to voluntary IFRS adopters, Bae et al. (2008) find for a sample of foreign analysts a negative relationship between GAAP differences and forecast accuracy, although this association is sensitive to the model specification.
} 
These findings appear at first to support the argument that IFRS adoption increases comparability, but arguably what these studies actually capture is familiarity rather than comparability (Bradshaw et al. 2004). A number of recent studies have attempted to directly test whether IFRS adoption increases comparability. The results are mixed. DeFond, Hu, Hung, and Li (2011), measuring comparability in terms of an increase in uniformity (Bielstein et al. 2007), find that mandatory IFRS adoption results in a greater increase in foreign investment for firms in countries with strong implementation credibility and an increase in comparability. Daske et al. (2008) find capital market benefits arising from mandating IFRS are most pronounced for firms that voluntarily adopted IFRS. This suggests possible comparability benefits but their subsequent analysis does not provide any support for this argument.

Other studies argue and find that cultural, political, and business differences continue to impose significant obstacles to increasing the comparability of accounting information. Cascino and Gassen (2010) find that pre-IFRS practices continue after mandatory adoption in Germany and Italy. Beneish, Miller, and Yohn (2010) find that mandatory IFRS adoption increases crossborder debt but not equity investments; this suggests that IFRS provides no comparability benefits in the equity markets. Lang, Maffett, and Owens (2010) find that accounting comparability does not improve for IFRS adopters relative to a control group of non-adopters and conclude that there is little evidence that IFRS adoption increases comparability.

Therefore, the empirical question remains as to whether the improvement in the information environment of analysts documented in prior literature is due to an increase in comparability. This leads to our first hypothesis:

HYPOTHESIS 1. Mandatory IFRS adoption provides comparability benefits and as a result affects analyst earnings forecast accuracy for firms adopting IFRS mandatorily.

\section{Information benefits}


Past research has shown that higher quality reporting reduces adverse selection in securities markets (Welker 1995; Healy et al. 1999; Lambert, Leuz, and Verrecchia 2007), reduces cost of capital (Botosan 1997; Hail and Leuz 2006), and improves the efficiency of information intermediaries (Lang and Lundholm 1996; Healy et al. 1999; Hope 2003). If IFRS are higher quality standards and provide better information then IFRS adoption has the potential to generate the above benefits. However, prior research has provided mixed evidence as to whether IFRS numbers are of higher quality relative to those associated with the application of domestic GAAP (Leuz and Wysocki 2008). Barth et al. (2008) find that firms' reporting quality increases after voluntary IFRS adoption. Horton and Serafeim (2010) find that IFRS reconciliations provide new information to investors even for firms that have already reported their performance under a high quality accounting regime (UK GAAP). Beuselinck et al. (2010) show that stock price synchronicity decreases after mandatory IFRS adoption, but this effect is temporary. Landsman, Maydew, and Thornock (2011) find that the information content of earnings announcement increases after adopting IFRS mandatorily, but only when using abnormal return volatility to proxy for information content rather than abnormal volume. Kim and Li (2010) find following mandatory IFRS an increase in intra-industry information transfer, particularly for those announcers with local GAAP diverging significantly from IFRS.

Various other studies fail to find strong evidence that IFRS improves the information set of investors and find limited or no capital market benefits for mandatory adopters. Daske et al. (2008) show that capital market benefits around mandatory adoption of IFRS are unlikely to exist primarily because of IFRS adoption. Daske (2006) finds no evidence that IFRS adoption decreases a firm's cost of capital. Atwood, Drake, Myers, and Myers (2011) find that earnings reported under IFRS are no more or less persistent and are no more or less associated with future cash flows than earnings reported under local GAAP. 
Therefore, the empirical question remains as to whether the improvement in the information environment of analysts documented in prior literature is due to an increase in information quality. This leads to our second hypothesis:

HYPOTHESIS 2. Mandatory IFRS adoption provides information quality benefits and as a result affects analyst earnings forecast accuracy for firms adopting IFRS mandatorily.

\section{Incentives and manipulation}

A stream of research argues that a firm's reporting incentives, and not accounting standards, is the primary factor that determines the informativeness of accounting statements (Ball, Kothari, and Robin 2000). As a result, if incentives do not change after IFRS adoption, mandating IFRS will have no effect on the information environment.

Opponents of IFRS argue that IFRS has increased managerial flexibility and discretion especially due to the lack of implementation guidance and poor enforcement (Ahmed, Neel, and Wang 2010; Ball et al. 2003; Leuz 2003). Consistent with the importance of incentives,

Christensen et al. (2008) find that incentives dominate standards in determining accounting quality around mandatory IFRS adoption. Following mandatory IFRS in Germany, Paananen (2008) and Paananen and Lin (2007) both find a decrease in financial reporting quality, an increase in earnings management, and a reduction in timeliness of loss recognition. Jeanjean and Stolowy (2008) find no decline in the pervasiveness of earnings management in Austria and the United Kingdom and find an increase in France. Both Ahmed et al. (2010) and Chen et al. (2010) find evidence of income smoothing and a reduction in timeliness of loss recognition following mandatory IFRS. However, contrary to Chen et al. (2010), Ahmed et al. (2010) find a significant increase in aggressive reporting of some accruals and no reduction in the management of earnings towards a target. Prior studies therefore suggest that there are increased opportunities for earnings 
management following IFRS. As a result, the documented increase in analysts' forecast accuracy could be a consequence of managers having more opportunities to manage their earnings towards analyst forecasts. Prior studies document that firms manage earnings towards a target (Bannister and Newman 1996; Degeorge, Patel, and Zeckhauser 1999; Matsumoto 2002; Abarbanell and Lehavy 2003; Hutton 2005). This leads to our third hypothesis:

HYPOTHESIS 3. The increase in forecast accuracy following mandatory IFRS is associated with increased opportunities for firms to manage earnings towards a target.

\section{Research design}

\section{Forecast accuracy}

To test our three hypotheses we first need to verify that the adoption of IFRS improves the information environment for the firms in our sample. Specifically, we test for differences in forecast errors before and after IFRS mandatory compliance for non-adopters, mandatory adopters, and voluntary adopters. We include voluntary adopters following the results of Byard et al. (2011) and Daske et al. (2008). Voluntary adopters, under this new mandatory setting, may benefit from positive externalities in terms of an increase in comparability and disclosure (Coffee 1984; Lambert et al. 2007; Daske et al. 2008). Following the mandatory adoption, there is now a larger pool in which intra-industry information transfers could take place. This could improve the information environment of voluntary adopters (Foster 1980; Ramnath 2002; Gleason, Jenkins, and Johnson 2008). Moreover, disclosure theory suggests that an increase in mandatory disclosure is paralleled by an increase in the incentives to voluntary disclosure; in other words, there is a 'race to the top' (Dye 1986, 1990).

Consistent with Daske et al. (2008), we control for the impact of potentially confounding events using non-adopting firms as our control sample. Any change in forecast accuracy for non- 
adopters will likely reflect the impact of concurrent economic and regulatory changes, but not the impact of mandatory IFRS adoption. I/B/E/S reports 12 consensus forecasts each year for a firm. We choose the consensus forecast that is calculated three months before fiscal year-end to ensure that analysts have adequate information generated by IFRS reporting to affect their forecast accuracy. We later use other consensus forecasts to assess the robustness of our results to the choice of forecast horizon. To test for the effect of IFRS adoption we use the following research design:

$F E_{i t}=\beta_{0}+\beta_{1}$ Mandatory $_{t}+\beta_{2}$ Voluntary IFRS $_{i} *$ Mandatory $_{t}$ $+\beta_{3}$ Mandatory IFRS I $_{i}$ Mandatory ${ }_{t}+\sum_{k=a}^{n} \beta_{k}$ controls $+\varepsilon_{i t}$

We define $F E_{i t}$ as the forecast error for firm $i$ and year $t$. Forecast error is the absolute difference between actual earnings and consensus forecast, deflated by absolute actual earnings. ${ }^{4}$ Voluntary $I F R S_{i}$ is an indicator variable that takes the value of one if firm $i$ adopted IFRS before IFRS was mandated. Mandatory IFRS is an indicator variable that takes the value of one if firm $i$ adopted IFRS after IFRS was mandated. Mandatory $t_{t}$ is an indicator variable that takes the value of one for years after 2005 (after 2003 for Singapore). $\beta_{1}$ captures the effect on firms that did not adopt IFRS, $\beta_{1}+\beta_{2}$ captures the effect on firms that voluntarily adopted IFRS early and $\beta_{1}+\beta_{3}$ captures the effect on firms that adopted IFRS mandatorily.

Model (1) includes only firms that have available data for periods both before and after the mandatory IFRS adoption. Previous research (Clement 1999; Duru and Reeb 2002; Bradshaw et al. 2010) suggests various factors that might affect forecast errors. We use these variables as controls in model (1). Control variables include 1) the level of absolute accruals, 2) analyst coverage, 3) the logarithm of the market value of the firm's equity, 4) reporting negative income,

\footnotetext{
${ }^{4}$ Following the findings of Cotter et al. 2010, we use absolute actual earnings rather than stock price as a deflator. Cotter et al. 2010 note in their study that using share price as the deflator meant it was not possible to rule our confounding effects since they acknowledge that their sample period 2003-07 included a period of high growth from 2004-06 followed by a severe decline from 2007 onwards. However, in unreported results we did use alternative deflators such as stock price and all the results were similar. We also find similar results if we do not deflate the forecast errors. Thus, the choice of deflator does not appear to be driving the results.
} 
and 5) forecast horizon (defined as the number of days between the forecast's issue date and the fiscal year end). We also include indicator variables for firms that report under U.S. GAAP or for firms that trade an ADR in the United States. We include the average forecast error, excluding the forecast error of the focal firm, of all firms in the same country-year and industry-year in model (1) to control for industry and countrywide time-varying effects. Moreover, we include firm fixed effects to control for persistent firm differences across the three groups of firms. We double cluster standard errors at the firm and at the year level to mitigate serial correlation within a firm or crosscorrelation among firms within a year.

To increase our confidence that it is IFRS adoption that causes the increase in forecast accuracy we also examine whether the firm-specific differences between IFRS and local GAAP earnings, captured in the firm's reconciliation document, are associated with the change in forecast accuracy following mandatory IFRS adoption. If IFRS adoption results in greater information quality and/or comparability then a priori those firms with the largest deviation of accounting practice from IFRS should have the most to gain from the transition to IFRS (Horton and Serafeim 2010; Beuselinck et al. 2010; Brochet et al. 2011).

We use as a proxy for the differences between local GAAP and IFRS a firm-level measure of the actual reported reconciliation component between IFRS and local GAAP earnings. ${ }^{5}$ This is available because firms were required in the first year of IFRS adoption to report the reconciliation between their last reported local GAAP accounts and IFRS. Therefore, we calculate the absolute difference between the firm's local GAAP earnings for 2004 and the reconciled IFRS earnings for 2004, as a percentage of absolute local GAAP earnings. ${ }^{6}$

\footnotetext{
5 One limitation of this proxy is that while we are able to capture the recognition and measurement differences within the reconciliation number, we are not able to capture disclosure differences which might also be associated with forecast accuracy. For example, segmental reporting disclosures pre and post, related party transaction pre and post etc.

${ }^{6}$ We find similar results if we scale the reconciliation amount with the market value of equity at the previous fiscal yearend.
} 


\section{Comparability and/or information effects}

\section{Comparability effects}

To test Hypothesis 1 and investigate the possibility of comparability effects of IFRS adoption we split the analyst sample into three groups. The first group is Local GAAP to IFRS that includes only analysts with portfolios consisting of firms that followed a single local GAAP prior to IFRS and then all switched to IFRS. For example, an analyst follows only firms whose financial statements use Spanish GAAP until 2004 and then they all switch to IFRS. We believe that for this subset of analysts comparability effects are negligible because these analysts focused on numbers generated by a single set of accounting principles both before and after mandatory IFRS adoption. The second group is Multiple GAAP to IFRS that includes only analysts with portfolios consisting of firms following different local GAAPs prior to IFRS (for example, some firms use French GAAP and others use German GAAP) and then all firms switched to IFRS. We believe that for this subset of analysts comparability increases because these analysts focused on numbers generated by different accounting principles before mandatory IFRS adoption but only from one set of accounting standards after mandatory adoption. The last group is Local GAAP to Multiple GAAP that includes analysts with portfolios including firms following a single local GAAP prior to IFRS and after mandatory IFRS some firms adopted IFRS and other firms continued to follow their local GAAP. We believe that for this subset of analysts comparability diminishes because these analysts focused on numbers generated from one set of accounting standards before mandatory IFRS adoption but from multiple sets of accounting standards after mandatory adoption. ${ }^{7}$ To hold information effects relatively homogeneous across the three groups of analysts we include in the analysis only forecasts made for mandatory adopters. We therefore exclude

\footnotetext{
${ }^{7}$ Embedded in the analysis is the assumption that analysts focus on specific stocks and therefore a change in accounting standards might increase, decrease, or have no effect on accounting comparability for an individual analyst (depending on the composition of the analyst's portfolio).
} 
voluntary adopters since the incremental information benefits following mandatory adoption are likely to be different than for firms implementing IFRS for the first time.

Moreover, to mitigate any selection bias that arises from analysts' choice to change coverage we restrict the analysis to firms that an analyst covers both before and after mandatory IFRS adoption. Control variables used in equation (1) are also included and we incorporate four additional variables to control for the individual analyst's attributes; for example, analyst's experience, number of firms covered, number of industries covered, and the size of the brokerage house they work for. This yields the following research design:

$$
\begin{aligned}
& F E_{i j t}=\beta_{0}+\beta_{1} \text { Local GAAP to IFRS }_{j}+\beta_{2} \text { Multiple GAAP to IFRS }{ }_{j}+\beta_{3} \text { Mandatory }_{t}+ \\
& \beta_{4} \text { Local GAAP to IFRS }_{j} * \text { Mandatory }{ }_{t}+\beta_{5} \text { Multiple GAAP to IFRS } \text { I }_{j} * \text { Mandatory }_{t} \\
& +\sum_{k=a}^{n} \beta_{k} \text { controls }+\varepsilon_{i j t}
\end{aligned}
$$

We define $F E_{i j t}$ as the forecast error for firm $i$, analyst $j$, and year $t$. Local GAAP to IFRS $S_{j}$ is an indicator variable and takes a value of one if analyst's $j$ portfolio only includes firms reporting under the same GAAP prior to IFRS. Multiple GAAP to IFRS $S_{j}$ is an indicator variable and takes a value of one if analyst's $j$ portfolio only includes firms reporting under different GAAPs prior to IFRS. If the increase in forecast accuracy is caused by greater comparability then we expect $\beta_{4}$ to be negative and significant and $\beta_{5}$ to be even more negative and significant.

\section{Information effects}

To test Hypothesis 2 and investigate the potential information effects of IFRS adoption we focus on the analyst group Multiple GAAP to IFRS. However, this time we use both the mandatory and the voluntary adopters. We expect that for this group of analysts comparability effects are present for both mandatory and voluntary adopters, but information effects are stronger for mandatory adopters if IFRS increases information quality. If voluntary adopters improve their level of disclosure substantially (Dye 1986) following mandatory IFRS adoption, then this introduces bias 
against the hypothesis. We also include all the control variables used in the comparability test above.

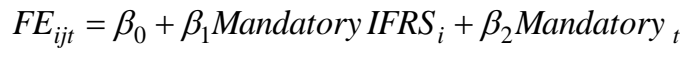

$+\beta_{3}$ Mandatory IFRS $_{i} *$ Mandatory $_{t}+\sum_{k=a}^{n} \beta_{k}$ controls $+\varepsilon_{i j t}$

If the increase in forecast accuracy is caused by an increase in information quality then we expect $\beta_{3}$ to be negative and significant.

\section{Manipulation effects}

To test Hypothesis 3 and investigate whether earnings manipulation can explain the predicted increase in forecast accuracy we estimate a number of models. The first model tests whether forecast accuracy improves more for mandatory adopters that have large absolute accruals. Accruals provide managers with discretion and allow them to alter the inter-temporal pattern of profit (Healy 1985). Second, we extend the model to test whether forecast accuracy improves more for mandatory adopters where analysts do not forecast cash flows. Prior studies find that firms followed by analysts who issue both earnings and cash flow forecasts exhibit lower levels of earnings management (DeFond and Hung 2003; McInnis and Collins 2010). Control variables used in equation (1) are also included.

$F E_{i t}=\beta_{0}+\beta_{1}$ Mandatory $_{t}+\beta_{2}$ Voluntary IFRS $_{i} *$ Mandatory $_{t}$ $+\beta_{3}$ Mandatory IFRS $_{i} *$ Mandatory $_{t}+$ $\beta_{4}$ Absolute Accruals $_{i t}+\beta_{5}$ Voluntary IFRS $_{i} *$ Mandatory $_{t} *$ Absolute Accruals $_{i t}$ $+\beta_{6}$ Mandatory IFRS $_{i} *$ Mandatory $_{t} *$ Absolute Accruals $_{i t}+\sum_{k=a}^{n} \beta_{k}$ controls $+\varepsilon_{i j t}$

where Absolute Accruals $s_{\text {it }}$ is the absolute difference between net income and cash flow, deflated by total assets, for firm $i$ and year $t$. If the increase in forecast accuracy is caused by earnings management then $\beta_{6}$ should be negative and significant. 
Finally, we examine if firms that now have more accruals under IFRS are more likely to meet or just beat analyst forecasts $\left(M T B T_{i t}\right)$. We employ the firm-specific reconciliation adjustment to capture the increased opportunities for firms to manipulate their earnings to meet analysts' forecasts. This change in accruals caused by IFRS adoption is captured in the firm's earnings reconciliation; for example, large reconciliation adjustment firms have high discretion and small reconciliation adjustment firms have low discretion. If IFRS adopters with the greatest discretion are managing their earnings then we should observe a higher probability for these firms meeting or just beating analysts' forecasts after IFRS adoption. Control variables used in equation (1) are also included.

$$
\begin{aligned}
& \text { MTBT }_{i t}=\beta_{0}+\beta_{1} \text { Mandatory }_{t}+\beta_{2} \text { GAAP Difference }_{i} * \text { Mandatory }_{t} \\
& +\sum_{k=a}^{n} \beta_{k} \text { controls }+\varepsilon_{i t}
\end{aligned}
$$

where $\mathrm{MTBT}_{\mathrm{it}}$ is an indicator variable that takes the value of one if for firm $i$ and year $t$ the realized earnings are equal to or greater than the analyst's consensus forecast by one cent per share. If the increase in forecast accuracy is caused by earnings management then $\beta_{2}$ should be positive and significant.

\section{Sample and descriptive statistics}

\section{Sample selection}

The sample covers firms from all countries with $\mathrm{I} / \mathrm{B} / \mathrm{E} / \mathrm{S}$ coverage and fiscal years ending on or after December 31, 2001 through December 31, 2007. We start by identifying all firms covered in I/B/E/S. We include only firms with I/B/E/S coverage both before and after IFRS adoption. We review annual reports to classify firms according to the accounting standards they are following and manually code each firm as adopting IFRS early ('voluntary adopters'), adopting IFRS mandatorily ('mandatory adopters'), or continuing to report under other GAAP after 2005 ('nonadopters'). 
This procedure yields in total 8,124 unique firms, of which 2,235 adopt IFRS for the first time mandatorily, and 635 firms had voluntarily adopted IFRS. Table 1 provides a breakdown of the sample into the number of firms and observations by country and by the accounting standards followed. The majority of mandatory adopters come from Australia, France, Singapore, Sweden, Hong Kong, and the United Kingdom. The majority of voluntary adopters are incorporated in Germany, Italy, and Switzerland. The composition of the sample is broadly consistent with Daske et al. (2008).

\section{[Insert Table 1]}

\section{Descriptive statistics}

Table 2, panel A reports summary statistics for the total sample. The mean and median deflated (un-deflated) forecast errors are 0.334 (2.873) and 0.107 (0.140), respectively. Mean forecast dispersion, consensus, common precision, and idiosyncratic precision are $0.148,0.585,113$, and 191 respectively. We measure consensus, common precision, and idiosyncratic precision consistent with Barron, Byard, and Kim (2002). Consensus is a measure of the commonality of beliefs among different analysts. Common precision is the inverse of the uncertainty in the information that is common across all analysts. Idiosyncratic precision is the inverse of uncertainty in the information that is idiosyncratic to each analyst. Mean and median analyst coverage is 7.4 and 5 , respectively. The forecast horizon is approximately 74 days.

Table 2, panel B reports summary statistics for voluntary adopters, mandatory adopters, and non-adopters. Voluntary adopters are larger than mandatory adopters and have higher analyst coverage. The level of absolute accruals is similar across the two groups. Voluntary adopters report losses more frequently than mandatory adopters. Non-adopters are moderately larger and have the same analyst coverage as mandatory adopters. The level of absolute accruals is also very similar to the level of absolute accruals for mandatory and voluntary adopters. The same is true for non-adopters excluding U.S. firms or including only firms from countries that mandated IFRS. 
Frequency of loss reporting for non-adopters is similar to frequency of loss reporting by mandatory adopters when U.S. firms are excluded.

[Insert Table 2]

\section{Results}

\section{Effect of mandatory IFRS adoption}

Varying the sample

Table 3 presents the estimated coefficients from multivariate regressions for different samples. We find that forecast accuracy improves significantly after mandatory IFRS adoption for mandatory and voluntary adopters relative to firms that do not adopt IFRS (column (1)). This improvement is significant at the 1 percent level for mandatory adopters and at the 10 percent for voluntary adopters. Column (2) excludes U.S. firms to assess the robustness of the results when the control group does not include U.S. firms. Forecast accuracy again improves for mandatory adopters, but accuracy for voluntary adopters does not significantly improve. Column (3) excludes forecasts made for 2005, the first year of mandatory IFRS adoption, because in 2005 there was still little information generated from IFRS adoption. We find significant decrease in forecast errors both for mandatory and voluntary adopters. Column (4) excludes forecasts made for 2001 and 2002. For these two years, the economy was in a recession. In contrast, for all the other years in the sample the economy was growing. Therefore, eliminating forecasts for 2001 and 2002 makes the periods before and after mandatory IFRS adoption more comparable in terms of economic conditions.

Forecast accuracy improves for mandatory adopters, but accuracy for voluntary adopters does not significantly improve. Estimating the model only on the countries that mandate IFRS produces similar results, with forecast accuracy improving only for mandatory adopters (column (5)). Finally, column (6) excludes firms from Singapore as it was the only country that mandated IFRS before 2005. Forecast accuracy improves significantly after mandatory IFRS adoption for 
mandatory adopters and marginally significantly for voluntary IFRS adopters. The coefficient on Mandatory IFRS * Mandatory is statistically greater than the coefficient on Voluntary IFRS * Mandatory at the 10 percent level in columns (1), (2), (4), and (6). This result suggests that the decrease in forecast errors is reliably greater for mandatory adopters relative to voluntary adopters under most specifications, although the level of statistical significance is moderate. The economic effect is approximately a 15 percent decrease in forecast errors for mandatory adopters relative to non-adopters.

\section{[Insert Table 3]}

Varying the measurement of the information environment

Table 4 estimates the same model but uses different dependent variables. The first column uses the un-deflated absolute difference between forecast and actual earnings. We use this alternative dependent variable to ensure that the results are not driven by the choice of the deflator. We find that forecast accuracy improves significantly after mandatory IFRS adoption for mandatory and voluntary IFRS adopters relative to firms that do not adopt IFRS (column (1)). This improvement is significant at the 1 percent level for mandatory adopters and significant at the 10 percent for voluntary adopters. Column (2) uses as dependent variable forecast dispersion divided by absolute actual earnings. Forecast dispersion declines significantly for both mandatory and voluntary adopters. This result might reflect an increase in the consensus across analysts and/or increased precision in forecasting (Barron, Kim, Lim, and Stevens 1998). To disentangle those two effects, we estimate the effect of IFRS reporting on analyst consensus (Barron, Bryard, and Kim 2002). Consensus decreases significantly for mandatory adopters relative to other firms (column (3)). This is contrary to the findings of Beuselinck et al. (2010), who find no change in the consensus. ${ }^{8}$ Consensus remains unchanged relative to other firms for voluntary adopters. Idiosyncratic and common precision increase for mandatory and voluntary adopters after mandatory IFRS adoption

\footnotetext{
${ }^{8}$ These results potentially differ as the sample in Beuselinck et al. (2010) is significantly smaller and the analysis does not control for time varying industry and country effects, and firm fixed effects.
} 
(columns (4) and (5)). ${ }^{9}$ The decrease in consensus for mandatory adopters can be explained by the higher increase in idiosyncratic precision compared to common precision. ${ }^{10}$

[Insert Table 4]

\section{Varying the forecast horizon}

Table 5 examines the robustness of the results to the choice of forecast horizon. Tables 3 and 4 use forecasts with an average horizon of about 70 days. Table 5 shows results using forecasts with horizons of 40, 100, 160 or 220 days. Overall, we find that forecast accuracy improves significantly more for mandatory adopters relative to other firms. Across all specifications, forecast accuracy improves more for mandatory adopters relative to non-adopters and the estimated effect is significant at the 1 percent level. Forecast accuracy does not improve significantly more for voluntary adopters relative to non-adopters. The coefficient on Mandatory IFRS * Mandatory is statistically greater than the coefficient on Voluntary IFRS * Mandatory at the 10 percent level in columns (1), (2), and (4). This result suggests that the decrease in forecast errors is reliably greater for mandatory adopters relative to voluntary adopters for most forecast horizons.

\section{[Insert Table 5]}

In summary, we find that the information environment improves for mandatory adopters. Macroeconomic factors and not IFRS adoption can cause the decrease in forecast errors, thereby casting doubt on whether IFRS causes the improvement in the information environment. However, these factors should affect the three groups of firms on average uniformly and therefore this argument fails to explain why we observe a higher improvement in transparency for mandatory

\footnotetext{
${ }^{9}$ Readers should interpret the decomposition of consensus to common and idiosyncratic precision with care. As Barron et al. (1998) note, the decomposition is valid if the following assumptions are satisfied: analysts issue unbiased forecasts, earnings forecast do not strictly determine earnings realizations, all analysts' idiosyncratic information is of equal precision, and forecast errors are equally distributed. We believe it may well be the case that the third assumption does not hold in our setting.

${ }^{10}$ We also rank transformed the idiosyncratic and common precision variables and estimated the effect of IFRS adoption on the ranking variables. The results were unchanged.
} 
adopters. Moreover, the inclusion of time-varying country, industry, and firm factors should mitigate concerns that other unrelated events systematically vary with the IFRS adoption samples and cause different behavior in our information environment measures.

\section{Firm-specific differences between IFRS and local GAAP}

If IFRS adoption has a direct effect on the information environment then the improvement in forecast accuracy should be higher for firms with larger reconciliation amounts. Table 6 confirms this prediction.

\section{[Insert Table 6]}

The sample includes 1,389 unique firms from 18 countries with available I/B/E/S and reconciliation data. ${ }^{11}$ The first two columns include all 1,389 firms. The last two columns exclude 427 UK firms, which heavily populate our sample, to ensure that the results are not driven only by UK firms. Columns (1) and (3) use raw values of the absolute deflated difference between Local GAAP and IFRS earnings. Columns (2) and (4) include rank values of this variable, ranging from one to five, where firms are assigned to quintiles. The interaction term GAAP Difference * Mandatory is negative and significant across all specifications and therefore forecast accuracy improves more for firms with domestic accounting practice diverging more from IFRS.

\section{Comparability and/or information effects}

Comparability effects

Table 7, panel A provides summary statistics for the three groups of analysts and the firms that each group covers. Analysts with portfolios that move from Local to Multiple GAAP work in brokerage houses with on average 80 analysts; follow a firm for a little over three years; cover 12

\footnotetext{
11 The sample includes firms from the following countries: Austria 2, Belgium 39, Czech Republic 1, Denmark 40, Finland 75, France 240, Greece 53, Ireland 27, Italy 109, Luxembourg 1, the Netherlands 85, Norway 57, Poland 6, Portugal 16, Spain 79, Sweden 115, Switzerland 17, and United Kingdom 427.
} 
firms; and five industries. ${ }^{12}$ Average horizon of first (last) forecast is 163 (102) days. Analysts with portfolios that move from Local GAAP to IFRS work in brokerage houses with on average 54 analysts, follow a firm for a little over three years, cover eight firms, and four industries. Average horizon of first (last) forecast is 173 (86) days. Analysts with portfolios that move from Multiple GAAP to IFRS work in brokerage houses with on average 88 analysts, follow a firm for a little over three years, cover nine firms, and four industries. Average horizon of first (last) forecast is 171 (88) days.

\section{[Insert Table 7]}

Table 7, panel B shows that consistent with a comparability effect, forecast accuracy improves more for analysts with portfolios that move from Local GAAP to IFRS and even more for analysts with portfolios that move from Multiple GAAP to IFRS. In the first (last) two columns, we use the first (last) forecast issued by each analyst within 250 days from fiscal year end. We use as a dependent variable both deflated and un-deflated absolute forecast errors. The coefficients on Local GAAP to IFRS * Mandatory and Multiple GAAP to IFRS * Mandatory are negative and, across all specifications, the latter is more negative than the former. Therefore, we find evidence consistent with Hypothesis 1. Forecast accuracy improves more for analysts that benefit more from increased accounting comparability after IFRS adoption.

In unreported tests, we examine whether the three groups of analysts differ substantially in terms of the covered firms' country institutions (enforcement, legal institutions etc.) or reconciliation magnitudes. If mandatory adopters covered by analysts with portfolios that move from Multiple GAAP to IFRS are incorporated in countries with stronger legal institutions or have larger reconciliation amounts then the results might be caused by enforcement or reconciliation amounts rather than comparability. However, in unreported results, we do not find any systematic

\footnotetext{
1232 percent of analysts are classified in this category. Analysts in this group cover on average more companies than other analysts, which makes it more likely that one of their firms will not switch after mandatory adoption. Moreover, at the same time, these analysts cover significantly smaller firms compared to other analysts; smaller firms in many jurisdictions switched to IFRS later on (and not in 2005).
} 
differences that could bias our results in either way. When we include control variables for the quality of country institutions or reconciliation magnitudes all results remain unchanged.

\section{Information Effects}

Table 8, panel A shows summary statistics for analysts with portfolios that move from Multiple GAAP to IFRS. These analysts work for brokerage houses that employ on average 83 analysts, have a little more of three years of firm-specific experience, cover nine firms, and four industries. The sample includes 719 mandatory and 345 voluntary adopters. The sample of mandatory and voluntary adopters is comparable in terms of forecast horizon, reporting losses, firm size, and level of absolute accruals.

[Insert Table 8]

Table 8, panel B shows that consistent with an information effect, forecast accuracy improves more for mandatory than for voluntary adopters, for the set of analysts with portfolios that move from Multiple GAAP to IFRS. In the first (last) two columns, we use the first (last) forecast issued by each analyst within 250 days from fiscal year end. We use as dependent variable both deflated and un-deflated absolute forecast errors. The coefficient on Mandatory IFRS * Mandatory is negative and significant. This result is consistent with Hypothesis 2. The increase in forecast accuracy can be partly attributed to greater information quality after mandatory IFRS adoption.

\section{Are the findings a result of earnings management?}

Table 9 shows that the results are not likely to be the result of earnings management. The coefficient on the triple interaction term Mandatory IFRS * Mandatory * Absolute accruals is insignificant (panel A, column (1)). A negative and significant coefficient would be consistent with an earnings management explanation as it would indicate that the reduction in the forecast error after IFRS adoption is more pronounced for mandatory adopters that have large accruals and 
as a result more opportunities to manage earnings. In unreported tests, we estimate discretionary accruals using the modified Jones model. We replace absolute accruals with absolute discretionary accruals in the regression. The results are similar to the ones reported above.

[Insert Table 9]

The second column examines how the effect of mandatory IFRS adoption varies with the percentage of analysts that issue a cash flow forecast for the firm. For the median firm, one out of three analysts with earnings forecasts also issue a cash flow forecast. The coefficient on the triple interaction term Mandatory IFRS * Mandatory * CF forecasts is insignificant (column (2)). A positive and significant coefficient would be consistent with an earnings management explanation, as it would indicate that the reduction in the forecast error after IFRS adoption is more pronounced for mandatory adopters where analysts do not forecast cash flows.

Table 9 panel B shows that firms with larger absolute earnings reconciliations are no more likely to meet or beat the consensus earnings forecasts after mandatory IFRS adoption. To support the manipulation hypothesis, the coefficient on the interaction term, GAAP Difference * Mandatory, needed to be positive and significant. Instead it is negative and insignificant. ${ }^{13}$ Collectively, the results fail to support Hypothesis 3. The decrease in forecast errors is not driven by managers manipulating earnings to bring them closer to consensus forecasts.

\section{Conclusion}

With more than 120 countries requiring or permitting the use of IFRS by publicly listed companies the question of whether such a global transition towards a single set of accounting standards has been met by the presumed benefits of higher information quality and accounting comparability still remains unanswered. To contribute to our knowledge in this important topic we investigate

\footnotetext{
13 In unreported results to control for the possibility that any cross-sectional variation we observe is due to the different levels of enforcement we include an enforcement proxy used in prior studies (Byard et al. 2011; Preiato et al. 2009; Cotter et al. 2010). The results are not sensitive to this inclusion.
} 
whether mandatory IFRS adoption improves firms' information environment. We find that after the mandatory transition to IFRS, forecast accuracy and other measures of the quality of the information environment improve significantly more for mandatory adopters. Moreover, we find that the larger the difference between IFRS earnings and local GAAP earnings the larger is the improvement in forecast accuracy. This result increases our confidence that IFRS adoption causes the improvement in the information environment.

More importantly, we provide evidence on whether the improvement in the information environment can be attributed to higher quality information and/or improved accounting comparability. We find results consistent with both information and comparability effects. Forecast accuracy improves more for analyst-firm pairs that are affected by either information or comparability benefits. We find no evidence suggesting that the increase in forecast accuracy is driven by earnings manipulation.

A number of caveats apply to our analysis. First, as in any study that exploits time-series variation from an exogenous event, it is hard to unambiguously attribute causality to the observed effects. It is possible that correlated omitted variables are driving the results although we have tried to carefully isolate the effect of IFRS adoption. We tried to isolate the economic effect of IFRS adoption by considering all three categories of firms and by using several different identification strategies. Second, similar to previous research (Lang and Lundholm 1996; Healy, Hutton, and Palepu 1999), we rely on the analyst forecast characteristics to measure changes in the information environment. To the extent that these proxies are not appropriate one needs to be cautious in interpreting our evidence.

We believe that these results have important implications for the debate on the globalization of accounting standards and for regulators that are considering a transition towards IFRS.

Although we make no claim with regard to the net cost or benefit of adoption, we do highlight that the effects of IFRS compliance are not homogeneous for all firms (even within the same country). 
Importantly, we show that IFRS adoption is likely to generate both information and comparability effects and improve the quality of information intermediation in capital markets; a key market institution that facilitates efficient allocation of resources towards its most productive uses. 


\section{References}

Abarbanell, J., and R. Lehavy. 2003. Biased forecasts or biased earnings? The role of reported earnings in explaining apparent bias and over-/underreaction in analysts' earnings forecasts. Journal of Accounting and Economics, 36 (1-3): 105-146.

Ahmed, A.S., M. J. Neel, and D. Wang. 2010. Does mandatory adoption of IFRS improve accounting quality? Preliminary evidence. Working paper, available online at SSRN: http://ssrn.com/abstract=1502909, retrieved July 26, 2011.

Armstrong, C., M. E. Barth, A. Jagolinzer, and E. J. Riedl. 2010. Market reaction to events surrounding the adoption of IFRS in Europe. The Accounting Review, 85(1): 31-61.

Ashbaugh, H., and M. Pincus. 2001. Domestic accounting standard, international accounting standards, and the predictability of earnings. Journal of Accounting Research, 39: 417-434.

Atwood, T. J., M.S. Drake, J.N. Myers, and L.A. Myers. 2011. Do earnings reported under IFRS tell us more about future earnings and cash flows? Journal of Accounting and Public Policy, 30(1): 103-121.

Bae, K., H. Tan, and M. Welker. 2008. International GAAP differences: the impact on foreign analysts. The Accounting Review 83(3): 593-628.

Ball, R. 2006. IFRS: Pros and cons for investors. Accounting and Business Research, International Accounting Policy Forum (2006): 5-27.

Ball, R., A. Robin, and J. Wu. 2003. Incentives versus standards: properties of accounting income in four East Asian countries and implications for the acceptance of IAS. Journal of Accounting and Economics 36(2003): 235-270.

Ball, R., S. P. Kothari, and A. Robin. 2000. The effect of international institutional factors of properties of accounting earnings. Journal of Accounting and Economics 29: 1-51.

Bannister, J.W., and H.A. Newman. 1996. Accrual usage to manage earnings toward financial analysts' forecasts. Review of Quantitative Finance and Accounting, 7 (3): 259-278.

Barron, O., O. Kim, S. Lim, and D. Stevens. 1998. Using analysts' forecasts to measure properties of analysts' information environment. The Accounting Review, 73: 421-433.

Barron, O., D. Byard, and O. Kim. 2002. Changes in analysts' information around earnings announcements. The Accounting Review, 77(4): 821-846.

Barth, M., W. Landsman, and M. Lang. 2008. International accounting standards and accounting quality. Journal of Accounting Research, 46: 467-728.

Beneish, M.D., B.P. Miller, and T.L. Yohn. 2010. The effect of IFRS adoption on cross-border investment in equity and debt markets. Working paper, Indiana University Bloomington, available online at http://papers.ssrn.com/sol3/papers.cfm?abstract_id=1403451, retrieved July 26, 2011. 
Beuselinck, C., P. Joos, and S. Van der Meulen. 2010. Mandatory adoption of IFRS and analysts' forecasts information properties. Working paper, available online at http://www.feb.ugent.be/nl/ondz/Activ/Kijker/BKJV_Analyst_21Oct2009_CB.pdf, retrieved July 26, 2011.

Bielstein, M.T., P.H. Munter, and W.J. Schinas. 2007. How the IFRS movement will affect financial reporting in the U.S. Published by KPMG's Department of Public Practice as part of the Defining Issues Series, New York.

Botosan, C. 1997. Disclosure level and the cost of equity capital. The Accounting Review 72: $323-$ 349.

Bradshaw, M., and G. S. Miller. 2007. Will harmonizing accounting standards really harmonize accounting? Evidence from non-U.S. firms adopting U.S. GAAP. Working paper, Harvard Business School.

Bradshaw, M., B. Bushee, and G. Miller. 2004. Accounting choice, home bias, and U.S. investment in non-U.S. firms. Journal of Accounting Research 42: 795-841.

Bradshaw, M., G. Miller, and G. Serafeim. 2010. Accounting method heterogeneity and analysts' forecasts. Working paper, Harvard Business School.

Brochet, F., A. Jagolinzer, and E.J. Riedl. 2011. Mandatory IFRS adoption and financial statement comparability. Working paper, Harvard Business School.

Byard, D., Y. Li, and Y. Yu. 2011. The effect of mandated IFRS adoption on analyst' forecast errors. Journal of Accounting Research, 49(1): 69-96.

Cascino, S., and J. Gassen. 2010. Mandatory IFRS adoption and accounting comparability. Working paper, available online at SSRN: http://ssrn.com/abstract=1402206, retrieved July 26, 2011.

Chen, H., Q. Tang, Y. Jiang, and Z. Lin. 2010. The role of international financial reporting standards in accounting quality: Evidence from the European Union. Journal of International Financial Management \& Accounting, 21(3): 220-278.

Christensen, H., E. Lee, and M. Walker. 2008. Incentives or standards: What determines accounting quality changes around IFRS adoption? Working paper, Manchester Business School.

Christensen, H., E. Lee, and M. Walker. 2009. Do IFRS reconciliations convey information? The effect of debt contracting. Journal of Accounting Research, 47: 1167-1199.

Clement, M. 1999. Analysts forecast accuracy: Do ability, resources and portfolio complexity matter? Journal of Accounting and Economics, 27: 285-303.

Choi, F.D.S., and G. Meek. 2005. International Accounting, 5th Edition, Prentice-Hall.

Coffee, J. 1984. Market failure and the economic case for a mandatory disclosure system. Virginia Law Review 70: 717-53. 
Cotter, J, A. Tarca, and M. Wee. 2010. IFRS adoption and analysts' earnings forecasts: Australian evidence. Accounting and Finance (forthcoming), available online http://onlinelibrary.wiley.com/doi/10.1111/j.1467-629X.2010.00392.x/abstract, retrieved Dec 29, 2011.

Covrig, V., M. DeFond, and M. Hung. 2007. Home bias, foreign mutual fund holdings, and the voluntary adoption of International Accounting Standards. Journal of Accounting Research 45: $41-70$.

Cuijpers, R., and W. Buijink. 2005. Voluntary adoption of non-local GAAP in the European Union: A study of determinants and consequences. European Accounting Review, 14: 487-524.

Daske, H. 2006. Economic benefits of adopting IFRS or U.S. GAAP - Has the expected cost of equity capital really decreased? Journal of Business Finance and Accounting, 33: 329-373.

Daske, H., L. Hail, C. Leuz, and R. Verdi. 2008. Mandatory IFRS reporting around the world: early evidence on the economic consequences. Journal of Accounting Research, 46: 1085-1142.

DeFond, M., and M.Hung. 2003. An empirical analysis of analysts' cash flows. Journal of Accounting and Economics, 35: 73-90.

DeFond, M., X. Hu, M. Hung, and S. Li. 2011. The impact of mandatory IFRS adoption on foreign mutual fund ownership: the role of comparability. Journal of Accounting and Economics 51: $240-258$.

Degeorge, F., J.Patel, and R. Zeckhauser. 1999. Earnings management to exceed thresholds. The Journal of Business, 72 (1): 1-34.

Duru, A., and D. Reeb. 2002. International diversification and analysts' forecast accuracy and bias. The Accounting Review, 77: 415-433.

Dye, R.A. 1986. Proprietary and nonproprietary disclosures. The Journal of Business, 59(2): 331366.

Dye, R.A. 1990. Mandatory versus voluntary disclosures: the cases of financial and real externalities. The Accounting Review, 65(1): 1-24.

Ernstberger, J., S. Krotter, and C. Stadler. 2008. Analysts' forecast accuracy in Germany: The effect of different accounting principles and changes of accounting principles. BuR-Business Research 1, 26-53.

Foster, G. 1980. Externalities and financial reporting. The Journal of Finance, 35: 521-533.

Gebhardt, W.R., C. Lee, and B. Swaminathan. 2001. Toward an implied cost of capital. Journal of Accounting Research, 39: 135-176.

Glaum, M., J. Baetge, A. Grothe, and T. Oberdoerster. 2011. Introduction of International Accounting Standards, disclosure quality and accuracy of analysts' earnings forecasts. European Accounting Review, 20(4): 1-38. 
Gleason, C., N. Jenkins, and W. Johnson. 2008. The contagion effect of accounting restatements. The Accounting Review, 83(1): 83-110.

Guan, Y., O.K. Hope, and T. Kang. 2006. Does similarity of local GAAP to U.S. GAAP explain analysts' forecasts accuracy? Journal of Contemporary Accounting and Economics, 2: 190-207.

Hail, L., and C. Leuz. 2006. International differences in the cost of equity capital: Do legal institutions and securities regulation matter? Journal of Accounting Research 44: 485-531.

Healy, P. 1985. The effect of bonus schemes on accounting decisions. Journal of Accounting and Economics, 7: 85-107.

Healy, P. M., A. P. Hutton, and K. G. Palepu. 1999. Stock performance and intermediation changes surrounding sustained increases in disclosure. Contemporary Accounting Research, 16: $485-520$.

Hodgdon, C., R.H. Tondkar, D.W. Harless, and A. Adhikari. 2008. Compliance with IFRS disclosure requirements and individual analysts' forecast errors. Journal of International Accounting, Auditing and Taxation, 17(1): 1-13.

Hope, O. 2003. Disclosure practices, enforcement of accounting standards and analysts' forecast accuracy: an international study. Journal of Accounting Research, 41: 235-272.

Horton, J., and G. Serafeim. 2010. Market reaction to and valuation of IFRS reconciliation adjustments: first evidence from the UK. Review of Accounting Studies 15: 725 -751.

Hung, M., and K.R. Subramanyam. 2007. Financial statement effects of adopting International Accounting Standards: the case of Germany. Review of Accounting Studies, 12(4): 623-657.

Hutton, A. P. 2005. Determinants of managerial earnings guidance prior to regulation fair disclosure and bias in analysts' earnings forecasts. Contemporary Accounting Research, 22(4): 867-914.

Jeanjean, T., and H. Stolowy. 2008. Do accounting standards matter? An exploratory analysis of earnings management before and after IFRS adoption. Journal of Accounting and Public Policy 27: 480-494.

Kim, Y. and S. Li. 2010. Mandatory IFRS adoption and intra-industry information transfers. Working paper, Santa Clara University.

Kvaal, E., and C.W. Nobes. 2010. International differences in IFRS policy choice. Accounting and Business Research, 40(2): 173-187.

Lambert, R., C. Leuz, and R. Verrecchia. 2007. Accounting information, disclosure, and the cost of capital. Journal of Accounting Research 45: 385-420.

Landsman, W.R., E.L. Maydew, and J.R. Thornock. 2011. The information content of annual earnings announcements and mandatory adoption of IFRS. Journal of Accounting \& Economics, forthcoming, available online at SSRN: http://ssrn.com/abstract=1337567, retrieved July 26, 2011. 
Lang, M., J. Raedy, and W. Wilson. 2006. Earnings management and cross listing: Are reconciled earnings comparable to U.S. earnings? Journal of Accounting and Economics, 42(1/2): 255-283.

Lang, M., and R. Lundholm. (1996). Corporate disclosure policy and analysts behavior. The Accounting Review, 71: 467-492.

Lang, M., K. Lins and D. Miller. 2003. ADRs, analysts, and accuracy: Does cross listing in the U.S. improve a firm's information environment and increase market value? Journal of Accounting Research, 41: 317-345.

Lang, M., M. Maffett, and E. Owens. 2010. Earnings co-movement and accounting comparability: The effects of mandatory IFRS adoption. Working paper, University of North Carolina.

Leuz, C. (2003). IAS versus U.S. GAAP: Information-asymmetry based evidence from Germany's new market. Journal of Accounting Research, 41(3): 445-472.

Leuz, C., and R.Verrecchia. 2000. The economic consequences of increased disclosure. Journal of Accounting Research, 38:91-124.

Leuz, C. and Wysocki, P. 2008. Economic consequences of financial reporting and disclosure regulation: A review and suggestions for future research. Working paper, University of Chicago.

Matsumoto, D. A. 2002. Management's incentives to avoid negative earnings surprises. The Accounting Review, 77(3): 483-514

McInnis, J., and D. W. Collins. 2010. The effect of cash flow forecasts on accruals quality and benchmark beating. Journal of Accounting and Economics 51: 219-239.

Paananen, M. 2008. Fair value accounting for goodwill under IFRS: An exploratory study of the comparability in France, Germany, and the United Kingdom. Working paper, available online at SSRN: http://ssrn.com/abstract=1275803, retrieved July 26, 2011.

Paananen, M., and C. Lin. 2007. The development of accounting quality of IAS and IFRS over time: The case of Germany. Working paper, available online at SSRN: http://ssrn.com/abstract=1066604, retrieved July 26, 2011.

Preiato, J., P. Brown, and A. Tarca. 2009. Mandatory IFRS and properties of analysts' forecasts: How much does enforcement matter? Working paper, University of Western Australia.

Quigley, J. 2007. Deloitte and Touche World meeting, Berlin, Germany.

Ramnath, S. 2002. Investors and analysts reactions to earnings announcements of related firms: an empirical analysis. Journal of Accounting Research, 40:1351-1376.

Schipper, K. 2005. The introduction of IAS in Europe: Implications for international convergence. European Accounting Review, 14: 101-126.

Soderstrom, N., and K. Sun. 2007. IFRS adoption and accounting quality: a review. European Accounting Review, 16: 675-702. 
Tan, H., S. Wang, and M. Welker. 2011. Foreign analysts following and forecast accuracy around mandatory IFRS adoptions. Journal of Accounting Research, 49(5): 1307-1357.

Wang, X., G. Young and Z. Zhuang. 2008. The effects of mandatory adoption of International Financial Reporting Standards on information environments. Working paper, paper presented at the American Accounting Association Annual meeting, Chicago, IL.

Welker, M. 1995. Disclosure policy, information asymmetry, and liquidity in equity markets. Contemporary Accounting Research 11: 801-827.

Yu, G. 2010. Accounting standards and international portfolio holdings: Analysis of cross-border holdings following mandatory adoption of IFRS. Working paper, available online at http://papers.ssrn.com/sol3/papers.cfm?abstract_id=1430589, retrieved July 26, 2011. 
TABLE 1

Sample composition by country and by accounting standard followed

\begin{tabular}{|c|c|c|c|c|c|c|c|c|}
\hline \multirow[b]{2}{*}{ Country } & \multicolumn{2}{|c|}{ All } & \multicolumn{2}{|c|}{ Mandatory IFRS } & \multicolumn{2}{|c|}{ Voluntary IFRS } & \multicolumn{2}{|c|}{ U.S. GAAP } \\
\hline & Firm-years & Unique firms & Firm-years & Unique firms & Firm-years & Unique firms & Firm-years & Unique firms \\
\hline ARGENTINA & 15 & 3 & 0 & 0 & 0 & 0 & 0 & 0 \\
\hline AUSTRALIA & 1480 & 253 & 484 & 244 & 12 & 2 & 0 & 0 \\
\hline AUSTRIA & 175 & 32 & 20 & 7 & 131 & 25 & 13 & 5 \\
\hline BELGIUM & 382 & 69 & 121 & 49 & 88 & 19 & 7 & 3 \\
\hline BERMUDA & 86 & 16 & 0 & 0 & 14 & 2 & 71 & 14 \\
\hline BRAZIL & 552 & 91 & 0 & 0 & 0 & 0 & 0 & 0 \\
\hline CANADA & 2082 & 364 & 0 & 0 & 0 & 0 & 114 & 27 \\
\hline CHILE & 169 & 30 & 0 & 0 & 0 & 0 & 0 & 0 \\
\hline CHINA & 595 & 121 & 0 & 0 & 275 & 59 & 15 & 3 \\
\hline CZECH REPUBLIC & 30 & 5 & 3 & 2 & 21 & 3 & 0 & 0 \\
\hline DENMARK & 365 & 62 & 123 & 47 & 74 & 15 & 0 & 0 \\
\hline EGYPT & 31 & 7 & 0 & 0 & 0 & 0 & 0 & 0 \\
\hline FINLAND & 541 & 88 & 206 & 74 & 66 & 14 & 0 & 0 \\
\hline FRANCE & 1514 & 266 & 563 & 230 & 190 & 31 & 24 & 5 \\
\hline GERMANY & 1592 & 278 & 232 & 100 & 879 & 166 & 321 & 93 \\
\hline GREECE & 332 & 59 & 137 & 54 & 25 & 5 & 6 & 3 \\
\hline HONG KONG & 1073 & 189 & 482 & 181 & 46 & 8 & 12 & 3 \\
\hline HUNGARY & 62 & 10 & 2 & 1 & 58 & 9 & 0 & 0 \\
\hline INDIA & 603 & 117 & 0 & 0 & 0 & 0 & 6 & 2 \\
\hline INDONESIA & 295 & 49 & 0 & 0 & 0 & 0 & 0 & 0 \\
\hline IRELAND & 216 & 39 & 83 & 34 & 0 & 0 & 19 & 4 \\
\hline ISRAEL & 187 & 35 & 0 & 0 & 0 & 0 & 105 & 20 \\
\hline ITALY & 681 & 120 & 43 & 15 & 578 & 103 & 12 & 2 \\
\hline JAPAN & 5977 & 1032 & 0 & 0 & 0 & 0 & 258 & 47 \\
\hline KOREA (SOUTH) & 241 & 56 & 0 & 0 & 0 & 0 & 0 & 0 \\
\hline LUXEMBOURG & 52 & 9 & 6 & 2 & 22 & 5 & 19 & 4 \\
\hline MALAYSIA & 845 & 161 & 0 & 0 & 0 & 0 & 0 & 0 \\
\hline MEXICO & 308 & 49 & 0 & 0 & 0 & 0 & 0 & 0 \\
\hline
\end{tabular}




\begin{tabular}{|c|c|c|c|c|c|c|c|c|}
\hline NETHERLANDS & 701 & 113 & 252 & 95 & 55 & 9 & 77 & 17 \\
\hline NEW ZEALAND & 240 & 41 & 0 & 0 & 0 & 0 & 0 & 0 \\
\hline NORWAY & 440 & 77 & 197 & 74 & 10 & 2 & 28 & 8 \\
\hline PERU & 45 & 8 & 0 & 0 & 0 & 0 & 0 & 0 \\
\hline PHILIPPINES & 204 & 34 & 83 & 34 & 0 & 0 & 0 & 0 \\
\hline POLAND & 122 & 21 & 38 & 15 & 38 & 6 & 0 & 0 \\
\hline PORTUGAL & 162 & 25 & 57 & 21 & 18 & 4 & 0 & 0 \\
\hline RUSSIA & 93 & 20 & 0 & 0 & 45 & 10 & 40 & 9 \\
\hline SINGAPORE & 586 & 110 & 370 & 103 & 13 & 3 & 31 & 6 \\
\hline SOUTH AFRICA & 637 & 105 & 203 & 95 & 53 & 9 & 0 & 0 \\
\hline SPAIN & 515 & 83 & 220 & 80 & 0 & 0 & 2 & 1 \\
\hline SWEDEN & 770 & 129 & 335 & 125 & 17 & 3 & 7 & 1 \\
\hline SWITZERLAND & 903 & 146 & 66 & 25 & 593 & 100 & 81 & 16 \\
\hline TAIWAN & 582 & 111 & 0 & 0 & 0 & 0 & 4 & 1 \\
\hline THAILAND & 656 & 125 & 0 & 0 & 0 & 0 & 0 & 0 \\
\hline TURKEY & 293 & 54 & 0 & 0 & 100 & 21 & 0 & 0 \\
\hline UNITED KINGDOM & 3162 & 591 & 1158 & 528 & 7 & 2 & 16 & 4 \\
\hline UNITED STATES & 16617 & 2721 & 0 & 0 & 0 & 0 & 16617 & 2721 \\
\hline TOTAL & 47209 & 8124 & 5484 & 2235 & 3428 & 635 & 17905 & 3019 \\
\hline
\end{tabular}

This table shows the composition of the sample by country and by accounting standard. We refer to Hong Kong as a country in our analyses, although, more appropriately, it has the status of a Special Administrative Region (SAR) of the People's Republic of China. Voluntary IFRS includes firms that adopted IFRS before it was mandated in its country. Mandatory IFRS includes firms that adopt IFRS when their country mandated IFRS reporting. U.S. GAAP includes firms reporting their primary financial statements under U.S. GAAP. The sample includes only countries with at least 10 firm-year observations. 
TABLE 2

Panel A: Summary statistics for variables used in regression analysis

\begin{tabular}{lrrrrr}
\hline Dependent variables & \multicolumn{1}{c}{ Mean } & \multicolumn{1}{c}{ STD } & \multicolumn{1}{c}{ Q3 } & Median & \multicolumn{1}{c}{ Q1 } \\
\hline Error (deflated) & 0.334 & 0.596 & 0.317 & 0.107 & 0.036 \\
Error (non-deflated) & 2.873 & 7.959 & 0.940 & 0.140 & 0.040 \\
Dispersion & 0.148 & 0.222 & 0.152 & 0.065 & 0.027 \\
Consensus & 0.585 & 0.351 & 0.919 & 0.681 & 0.244 \\
Common precision & 112.910 & 243.126 & 75.623 & 9.073 & 0.747 \\
Idiosyncratic precision & 190.816 & 475.320 & 77.836 & 6.091 & 0.318 \\
\hline Independent variables & & & & & \\
\hline Absolute accruals & 0.042 & 0.043 & 0.055 & 0.036 & 0.019 \\
Analyst coverage & 7.397 & 6.484 & 10.000 & 5.000 & 3.000 \\
Firm size & 8.108 & 2.808 & 9.864 & 7.684 & 6.064 \\
Loss & 0.137 & 0.344 & 0.000 & 0.000 & 0.000 \\
Forecast horizon & 73.576 & 2.081 & 75.000 & 73.000 & 72.000 \\
ADR & 0.095 & 0.293 & 0.000 & 0.000 & 0.000 \\
\hline
\end{tabular}

Panel B: Summary statistics by type of IFRS adoption

\begin{tabular}{lccrrc}
\hline Mandatory adopters & Mean & \multicolumn{1}{c}{ STD } & \multicolumn{1}{c}{ Q3 } & Median & Q1 \\
\hline Absolute accruals & 0.043 & 0.042 & 0.057 & 0.037 & 0.018 \\
Analyst coverage & 7.370 & 6.659 & 10.000 & 5.000 & 2.000 \\
Firm size & 7.358 & 2.340 & 8.879 & 7.159 & 5.662 \\
Loss & 0.103 & 0.304 & 0.000 & 0.000 & 0.000 \\
\hline Voluntary adopters & & & & & \\
\hline Absolute accruals & 0.046 & 0.037 & 0.060 & 0.041 & 0.024 \\
Analyst coverage & 8.807 & 8.242 & 12.000 & 6.000 & 3.000 \\
Firm size & 7.667 & 2.438 & 9.177 & 7.555 & 5.890 \\
Loss & 0.141 & 0.348 & 0.000 & 0.000 & 0.000 \\
\hline Non-adopters & & & & & \\
\hline Absolute accruals & 0.042 & 0.043 & 0.053 & 0.034 & 0.019 \\
Analyst coverage & 7.237 & 6.140 & 10.000 & 5.000 & 3.000 \\
Firm size & 8.070 & 2.954 & 10.429 & 7.653 & 6.291
\end{tabular}




\begin{tabular}{lrrrrr} 
Loss & 0.130 & 0.307 & 0.000 & 0.000 & 0.000 \\
\hline Non-adopters (excl. U.S.) & & & & & \\
\hline Absolute accruals & 0.042 & 0.039 & 0.053 & 0.035 & 0.020 \\
Analyst coverage & 6.573 & 5.630 & 9.000 & 5.000 & 2.000 \\
Firm size & 7.827 & 2.116 & 10.259 & 7.360 & 6.907 \\
Loss & 0.122 & 0.327 & 0.000 & 0.000 & 0.000 \\
\hline Non-adopters (from mandatory countries) & & & & & \\
\hline Absolute accruals & 0.047 & 0.040 & 0.058 & 0.038 & 0.023 \\
Analyst coverage & 8.108 & 9.060 & 13.000 & 4.000 & 1.000 \\
Firm size & 6.378 & 2.484 & 8.336 & 6.216 & 4.587 \\
Loss & 0.214 & 0.410 & 0.000 & 0.000 & 0.000 \\
\hline
\end{tabular}

Error (deflated) is the absolute difference between consensus forecast and actual earnings, divided by absolute actual earnings. Error (non-deflated) is the absolute difference between consensus forecast and actual earnings. Dispersion is the standard deviation of individual analyst forecasts for a firm $i$ in year $t$ divided by absolute actual earnings. Consensus is a measure of the commonality in analysts' information, as captured by the across-analyst correlation in forecast errors (Barron, Byard and Kim 2002). Common precision is a measure of the precision of common information in individual analyst forecasts (Barron et al. 2002). Idiosyncratic precision is a measure of the precision of idiosyncratic information in individual analyst forecasts (Barron et al. 2002). Absolute accruals is the absolute difference between net income and cash flows, divided by total assets. Analyst coverage is the number of analysts providing earnings forecasts for a firm. Firm size is the natural logarithm of total assets. Loss is an indicator variable if a firm is reporting negative net income. Forecast horizon is the number of days between consensus forecast and end of forecasting period. ADR is an indicator variable if firm $i$ in year $t$ trades ADR in the United States. 
TABLE 3

Effect of mandatory IFRS adoption on information environment - Varying the sample

\begin{tabular}{|c|c|c|c|c|c|c|c|c|c|c|c|c|}
\hline \multirow{3}{*}{$\begin{array}{l}\text { Sample } \\
\text { Dependent variable }\end{array}$} & \multicolumn{2}{|c|}{ All firms } & \multicolumn{2}{|c|}{ Ex U.S. } & \multicolumn{2}{|c|}{ Ex 2005} & \multicolumn{2}{|c|}{ Ex 2001-2002 } & \multicolumn{2}{|c|}{ Mandatory countries } & \multicolumn{2}{|c|}{ Ex Singapore } \\
\hline & \multicolumn{2}{|c|}{ (1) } & \multicolumn{2}{|c|}{ (2) } & \multicolumn{2}{|c|}{ (3) } & \multicolumn{2}{|c|}{ (4) } & \multicolumn{2}{|c|}{$(5)$} & \multicolumn{2}{|c|}{$(6)$} \\
\hline & & & & & & Error & deflated) & & & & & \\
\hline Parameter & Estimate & $\mathrm{t}$ & Estimate & $\mathrm{t}$ & Estimate & $\mathrm{t}$ & Estimate & $\mathrm{t}$ & Estimate & $\mathrm{t}$ & Estimate & $\mathrm{t}$ \\
\hline Intercept & -0.4520 & -5.02 & -0.3011 & -2.23 & -0.5400 & -5.45 & -0.3880 & -3.75 & -0.3034 & -1.73 & -0.3996 & -4.42 \\
\hline Mandatory & 0.0070 & 0.98 & -0.0122 & -1.13 & 0.0105 & 1.30 & 0.0000 & -0.01 & -0.0147 & -0.75 & 0.0041 & 0.58 \\
\hline Voluntary IFRS * Mandatory & -0.0398 & -1.86 & -0.0227 & -1.03 & -0.0581 & -2.52 & -0.0062 & -0.28 & -0.0216 & -0.75 & -0.0404 & -1.88 \\
\hline Mandatory IFRS * Mandatory & -0.0474 & -4.32 & -0.0343 & -2.80 & -0.0572 & -4.44 & -0.0357 & -2.90 & $-\mathbf{0 . 0 3 0 3}$ & -1.99 & -0.0494 & -4.36 \\
\hline Absolute accruals & -0.2807 & -6.74 & -0.2875 & -4.97 & -0.2815 & -6.07 & -0.1622 & -2.66 & -0.3723 & -4.49 & -0.2737 & -6.53 \\
\hline U.S. GAAP & 0.0680 & 13.44 & -0.0350 & -2.95 & 0.0710 & 11.39 & 0.0728 & 10.46 & -0.0570 & -2.48 & 0.0676 & 13.40 \\
\hline Analyst coverage & -0.0010 & -4.17 & -0.0011 & -3.40 & -0.0011 & -4.00 & -0.0012 & -3.57 & -0.0013 & -3.02 & -0.0009 & -4.07 \\
\hline Firm size & 0.0064 & 11.39 & 0.0054 & 8.62 & 0.0073 & 10.11 & 0.0065 & 6.95 & 0.0076 & 6.26 & 0.0063 & 11.30 \\
\hline Loss & 0.2997 & 26.96 & 0.3879 & 24.00 & 0.2942 & 25.03 & 0.3082 & 23.48 & 0.3556 & 16.01 & 0.2998 & 26.89 \\
\hline Forecast horizon & 0.0023 & 2.03 & 0.0005 & 0.27 & 0.0033 & 2.60 & 0.0014 & 1.11 & 0.0004 & 0.16 & 0.0017 & 1.45 \\
\hline ADR & -0.0174 & -5.58 & -0.0018 & -0.48 & -0.0076 & -1.62 & -0.0282 & -3.82 & -0.0025 & -0.47 & -0.0171 & -5.39 \\
\hline Industry-year benchmark & 0.1064 & 3.93 & 0.0955 & 2.49 & 0.1206 & 4.07 & 0.1432 & 3.69 & 0.1755 & 3.28 & 0.1008 & 3.72 \\
\hline Country-year benchmark & 0.4542 & 21.12 & 0.4543 & 18.30 & 0.4470 & 19.38 & 0.4795 & 15.30 & 0.4305 & 12.22 & 0.4527 & 20.72 \\
\hline Firm effects & Yes & & Yes & & Yes & & Yes & & Yes & & Yes & \\
\hline Adj R-squared & $38.8 \%$ & & $39.0 \%$ & & $38.8 \%$ & & $37.1 \%$ & & $40.1 \%$ & & $38.7 \%$ & \\
\hline $\mathrm{N}$ & 47,209 & & 30,592 & & 39,898 & & 35,284 & & 16,697 & & 46,623 & \\
\hline
\end{tabular}

This table presents OLS specifications testing the effect of IFRS adoption on forecast errors. 'All firms' includes the firms in Table 1. 'Excl. U.S.' excludes U.S.

firms. 'Excl. 2005' excludes forecasts made for the fiscal year of 2005. 'Excl. 2001-2002' excludes all forecasts made for fiscal years 2001 and 2002.

'Mandatory countries' includes only forecasts made for firms in countries that mandated IFRS. 'Excl. Singapore' excludes all firms from Singapore. Dependent variable is Error (deflated), which is the absolute difference between consensus forecast and actual earnings, divided by absolute actual earnings. Voluntary IFRS is an indicator variable for a firm that adopted IFRS before it was mandated in its country. Mandatory IFRS is an indicator variable that takes the value of one for a firm that adopts IFRS when its country mandated IFRS. Mandatory is an indicator variable that takes the value of one for periods on or after 2005 (2003 for Singapore). U.S. GAAP is an indicator variable that takes the value of one if a firm reports under U.S. GAAP. Industry-year benchmark is the average level of the dependent variable by year for each of the 49 Fama-French (1996) industries. Country-year benchmark is the average level of the dependent variable by year for each country. Standard errors are robust to heteroscedasticity and clustered at the firm and year level. All other variable definitions are provided in Table 2 . 
TABLE 4

Effect of mandatory IFRS adoption on information environment - Varying the dependent variable

\begin{tabular}{|c|c|c|c|c|c|c|c|c|c|c|}
\hline \multirow{3}{*}{$\begin{array}{l}\text { Dependent variable } \\
\text { Parameter }\end{array}$} & \multirow{2}{*}{\multicolumn{2}{|c|}{$\begin{array}{c}\text { Error (non-deflated) } \\
(1)\end{array}$}} & \multirow{2}{*}{\multicolumn{2}{|c|}{$\frac{\text { Dispersion }}{\text { (2) }}$}} & \multicolumn{2}{|c|}{ Consensus } & \multirow{2}{*}{\multicolumn{2}{|c|}{$\begin{array}{c}\text { Common precision } \\
\text { (4) }\end{array}$}} & \multirow{2}{*}{\multicolumn{2}{|c|}{$\frac{\text { Idiosyncratic precision }}{(5)}$}} \\
\hline & & & & & & & & & & \\
\hline & Estimate & $\mathrm{t}$ & Estimate & $\mathrm{t}$ & Estimate & $\mathrm{t}$ & Estimate & $\mathrm{t}$ & Estimate & $\mathrm{t}$ \\
\hline Intercept & -2.4920 & -3.68 & -0.0767 & -2.26 & -0.6969 & -11.37 & 21.1478 & 0.58 & 88.4537 & 1.17 \\
\hline Mandatory & 0.0527 & 0.85 & -0.0055 & -2.20 & 0.0140 & 3.28 & -18.2047 & -6.49 & -26.5746 & -4.56 \\
\hline Voluntary IFRS * Mandatory & -0.2306 & -1.80 & -0.0256 & -2.96 & 0.0015 & 0.12 & 24.7885 & 5.37 & 21.4534 & 2.23 \\
\hline Mandatory IFRS * Mandatory & -0.2330 & -2.49 & -0.0129 & -3.17 & -0.0215 & -2.98 & 19.0527 & 5.35 & 32.5467 & 4.39 \\
\hline Absolute accruals & -0.8379 & -2.23 & -0.1044 & -6.80 & 0.0054 & 0.20 & -4.7230 & -0.43 & -9.1444 & -0.40 \\
\hline U.S. GAAP & 0.1017 & 4.23 & 0.0310 & 15.87 & -0.0284 & -12.31 & -12.8968 & -10.76 & -18.8442 & -9.81 \\
\hline Analyst coverage & 0.0042 & 2.35 & -0.0003 & -2.80 & -0.0008 & -5.68 & -0.3540 & -4.48 & -0.1634 & -0.98 \\
\hline Firm size & 0.0573 & 10.58 & 0.0012 & 6.11 & 0.0012 & 4.34 & -0.1178 & -0.83 & -0.4663 & -1.56 \\
\hline Loss & 1.9249 & 20.85 & 0.0539 & 13.30 & 0.0632 & 16.76 & -22.0241 & -16.10 & -37.4354 & -14.64 \\
\hline Forecast horizon & 0.0172 & 1.97 & -0.0003 & -0.80 & 0.0030 & 3.72 & -0.3275 & -0.68 & -1.3330 & -1.32 \\
\hline ADR & -0.1179 & -5.86 & -0.0060 & -5.23 & 0.0088 & 6.10 & 4.0532 & 6.90 & 4.5297 & 4.32 \\
\hline Industry-year benchmark & 0.1036 & 4.70 & 0.2033 & 9.72 & 0.2153 & 6.32 & 0.1234 & 9.23 & 0.1349 & 6.86 \\
\hline Country-year benchmark & 0.0340 & 8.18 & 0.4166 & 25.26 & 0.6057 & 21.87 & 0.1187 & 13.83 & 0.1103 & 11.55 \\
\hline Firm effects & Yes & & Yes & & Yes & & Yes & & Yes & \\
\hline Adj R-squared & $74.1 \%$ & & $44.4 \%$ & & $26.1 \%$ & & $53.6 \%$ & & $43.4 \%$ & \\
\hline $\mathrm{N}$ & 47,209 & & 41,028 & & 40,951 & & 40,951 & & 40,951 & \\
\hline
\end{tabular}

This table presents OLS specifications testing the effect of mandatory IFRS adoption on measures of information environment quality. Error (non-deflated) is the absolute difference between consensus forecast and actual earnings. Dispersion is the standard deviation of individual analyst forecasts divided by absolute actual earnings. Consensus is a measure of the commonality in analysts' information, as captured by the across-analyst correlation in forecast errors (Barron et al. 2002). Common precision is a measure of the precision of common information in individual analyst forecasts (Barron et al. 2002). Idiosyncratic precision is a measure of the precision of idiosyncratic information in individual analyst forecasts (Barron et al. 2002). Voluntary IFRS is an indicator variable for a firm that adopted IFRS before it was mandated in its country. Mandatory IFRS is an indicator variable that takes the value of one for a firm that adopts IFRS when its country mandated IFRS reporting. Mandatory is an indicator variable that takes the value of one for periods on or after 2005 (2003 for Singapore). Industry-year 
benchmark is the average level of the dependent variable by year for each of the 49 Fama-French (1996) industries. Country-year benchmark is the average level of the dependent variable by year for each country. All other variable definitions are provided in Table 2. Standard errors are robust to heteroscedasticity and clustered at the firm and year level. 
TABLE 5

Effect of mandatory IFRS adoption on information environment - Varying the forecast horizon

\begin{tabular}{|c|c|c|c|c|c|c|c|c|}
\hline \multirow{3}{*}{$\begin{array}{l}\text { Sample } \\
\text { Dependent variable }\end{array}$} & \multicolumn{2}{|c|}{ Horizon 40 days } & \multicolumn{2}{|c|}{ Horizon 100 days } & \multicolumn{2}{|c|}{ Horizon 160 days } & \multicolumn{2}{|c|}{ Horizon 220 days } \\
\hline & \multicolumn{2}{|c|}{ (1) } & \multicolumn{2}{|c|}{$(2)$} & \multicolumn{2}{|c|}{ (3) } & \multicolumn{2}{|c|}{ (4) } \\
\hline & & & & Error & flated) & & & \\
\hline Parameter & Estimate & $\mathrm{t}$ & Estimate & $\mathrm{t}$ & Estimate & $\mathrm{t}$ & Estimate & $\mathrm{t}$ \\
\hline Intercept & -0.1801 & -4.22 & -0.3630 & -4.59 & -0.6696 & -5.65 & -0.8941 & -6.05 \\
\hline Mandatory & 0.0030 & 0.50 & 0.0022 & 0.32 & 0.0012 & 0.17 & 0.0070 & 0.92 \\
\hline Voluntary IFRS * Mandatory & -0.0377 & -1.83 & -0.0332 & -1.48 & -0.0366 & -1.43 & -0.0121 & -0.42 \\
\hline Mandatory IFRS * Mandatory & -0.0508 & -4.73 & -0.0500 & -4.21 & -0.0389 & -2.94 & -0.0433 & -2.90 \\
\hline Absolute accruals & -0.2380 & -6.48 & -0.2953 & -6.97 & -0.3741 & -7.41 & -0.3086 & -5.45 \\
\hline U.S. GAAP & 0.0715 & 14.16 & 0.0645 & 12.25 & 0.0671 & 11.39 & 0.0804 & 12.66 \\
\hline Analyst coverage & -0.0010 & -4.74 & -0.0009 & -3.51 & -0.0002 & -0.86 & 0.0002 & 0.55 \\
\hline Firm size & 0.0057 & 11.53 & 0.0079 & 13.10 & 0.0070 & 10.03 & 0.0063 & 7.91 \\
\hline Loss & 0.2539 & 25.43 & 0.3121 & 26.55 & 0.3758 & 28.49 & 0.3985 & 28.02 \\
\hline Forecast horizon & -0.0016 & -1.58 & 0.0004 & 0.55 & 0.0017 & 2.48 & 0.0020 & 3.08 \\
\hline ADR & -0.0184 & -6.34 & -0.0199 & -5.92 & -0.0217 & -5.56 & -0.0283 & -6.78 \\
\hline Industry-year benchmark & 0.1192 & 4.27 & 0.1460 & 5.78 & 0.1560 & 7.11 & 0.1541 & 6.75 \\
\hline Country-year benchmark & 0.4528 & 21.50 & 0.4685 & 21.12 & 0.4982 & 21.25 & 0.5619 & 22.93 \\
\hline Firm effects & Yes & & Yes & & Yes & & Yes & \\
\hline Adj R-squared & $38.4 \%$ & & $39.8 \%$ & & $41.5 \%$ & & $42.6 \%$ & \\
\hline $\mathrm{N}$ & 48,067 & & 45,301 & & 43,069 & & 38,893 & \\
\hline
\end{tabular}

This table presents OLS specifications testing the effect of mandatory IFRS adoption on forecast errors. Horizon 40 days includes forecasts on average 40 days away from the end of the fiscal period. Horizon 100 days includes forecasts on average 100 days away from the end of the fiscal period. Horizon 160 days includes forecasts on average 160 days away from the end of the fiscal period. Horizon 220 days includes forecasts on average 220 days away from the end of the fiscal period. Dependent variable is Error (deflated), which is the absolute difference between consensus forecast and actual earnings, divided by absolute actual earnings. Voluntary IFRS is an indicator variable for a firm that adopted IFRS before it was mandated in its country. Mandatory IFRS is an indicator variable that takes the value of one for a firm that adopts IFRS when its country mandated IFRS reporting. Mandatory is an indicator variable that takes the value of one for periods on or after 2005 (2003 for Singapore),. Industry-year benchmark is the average level of the dependent variable by year for each of the 49 Fama-French 
(1996) industries. Country-year benchmark is the average level of the dependent variable by year for each country. All other variable definitions are provided in Table 2. Standard errors are robust to heteroscedasticity and clustered at the firm and year level. 
TABLE 6

Effect of mandatory IFRS adoption on information environment -Firm-specific differences between IFRS and local GAAP

\begin{tabular}{|c|c|c|c|c|c|c|c|c|}
\hline \multirow{3}{*}{$\begin{array}{l}\text { Sample } \\
\text { Dependent variable }\end{array}$} & \multicolumn{4}{|c|}{ Mandatory adopters } & \multicolumn{4}{|c|}{ Mandatory adopters excl. UK } \\
\hline & \multicolumn{2}{|c|}{ (1) } & \multicolumn{2}{|c|}{ (2) } & \multicolumn{2}{|c|}{ (3) } & \multicolumn{2}{|c|}{ (4) } \\
\hline & \multicolumn{8}{|c|}{ Error (deflated) } \\
\hline Parameter & Estimate & $\mathrm{t}$ & Estimate & $\mathrm{t}$ & Estimate & $\mathrm{t}$ & Estimate & $\mathrm{t}$ \\
\hline Intercept & -0.3119 & -1.30 & -0.3274 & -1.36 & 0.4527 & 1.24 & 0.4354 & 1.19 \\
\hline Mandatory & -0.0288 & -1.51 & 0.0739 & 2.32 & -0.0500 & -1.99 & 0.0419 & 1.11 \\
\hline GAAP Difference & 0.0091 & 3.15 & 0.0237 & 4.84 & 0.0095 & 2.71 & 0.0211 & 3.66 \\
\hline GAAP Difference * Mandatory & -0.0133 & -2.19 & -0.0413 & -4.36 & -0.0130 & -1.98 & -0.0375 & -3.26 \\
\hline Absolute accruals & -0.2530 & -2.05 & -0.2825 & -2.35 & -0.4311 & -3.08 & -0.4472 & -3.23 \\
\hline U.S. GAAP & -0.1987 & -2.98 & -0.1836 & -2.80 & -0.1904 & -2.83 & -0.1781 & -2.69 \\
\hline Analyst coverage & -0.0021 & -3.01 & -0.0019 & -2.78 & -0.0009 & -1.25 & -0.0007 & -0.99 \\
\hline Firm size & 0.0065 & 3.14 & 0.0060 & 2.91 & 0.0031 & 1.49 & 0.0027 & 1.27 \\
\hline Loss & 0.3487 & 11.05 & 0.3459 & 10.99 & 0.3644 & 10.38 & 0.3610 & 10.27 \\
\hline Forecast horizon & 0.0008 & 0.25 & 0.0003 & 0.10 & -0.0091 & -1.96 & -0.0095 & -2.03 \\
\hline ADR & 0.0092 & 1.16 & 0.0078 & 0.99 & 0.0037 & 0.39 & 0.0019 & 0.20 \\
\hline Industry-year benchmark & 0.1782 & 2.41 & 0.1773 & 2.40 & 0.1233 & 1.39 & 0.1254 & 1.42 \\
\hline Country-year benchmark & 0.4420 & 7.98 & 0.4329 & 7.86 & 0.4563 & 7.75 & 0.4447 & 7.60 \\
\hline Firm effects & Yes & & Yes & & Yes & & Yes & \\
\hline Adj R-squared & $41.2 \%$ & & $41.3 \%$ & & $42.7 \%$ & & $42.7 \%$ & \\
\hline $\mathrm{N}$ & 8,168 & & 8,168 & & 5,709 & & 5,709 & \\
\hline
\end{tabular}

This table presents OLS specifications testing the effect of mandatory IFRS adoption on forecast errors. Mandatory adopters includes all firms that are mandatory adopters of IFRS with available IFRS reconciliation and IBES data. Mandatory adopter's excl. UK includes all firms that are mandatory adopters of IFRS with available IFRS reconciliation and IBES data outside the United Kingdom. The first and third column use raw values of GAAP difference. The second and third column use rank values (ranging from one to five) of GAAP difference. Dependent variable is Error (deflated), which is the absolute difference between consensus forecast and actual earnings, divided by absolute actual earnings. Mandatory is an indicator variable that takes the value of one for periods on or after 2005. GAAP difference is the absolute difference between IFRS earnings and local GAAP earnings, as published in the reconciliation documents of first time adopters in 2005 , divided by the absolute local GAAP earnings. Industry-year benchmark is the average level of the dependent variable by year for each of the 49 
Fama-French (1996) industries. Country-year benchmark is the average level of the dependent variable by year for each country. All other variable definitions are provided in Table 2. Standard errors are robust to heteroscedasticity and clustered at the firm and year level. 
TABLE 7

Panel A: Summary statistics by analyst classification

\begin{tabular}{|c|c|c|c|c|c|c|}
\hline Analyst group & \multicolumn{2}{|c|}{ From Local to Multiple GAAP } & \multicolumn{2}{|c|}{ From Local GAAP to IFRS } & \multicolumn{2}{|c|}{ From Multiple GAAP to IFRS } \\
\hline \# of observations & \multicolumn{2}{|c|}{8152} & \multicolumn{2}{|c|}{2874} & \multicolumn{2}{|c|}{9538} \\
\hline \# of unique firms & \multicolumn{2}{|c|}{1009} & \multicolumn{2}{|c|}{384} & \multicolumn{2}{|c|}{719} \\
\hline \# of unique analysts & \multicolumn{2}{|c|}{426} & \multicolumn{2}{|c|}{197} & \multicolumn{2}{|c|}{706} \\
\hline Statistic & Mean & STD & Mean & STD & Mean & STD \\
\hline Error (deflated) -(First forecast) & 0.406 & 1.196 & 0.484 & 1.327 & 0.495 & 1.389 \\
\hline Error (non-deflated) - (First forecast) & 2.784 & 13.008 & 2.765 & 13.346 & 2.272 & 18.110 \\
\hline Error (deflated) - (Last forecast) & 0.339 & 1.090 & 0.381 & 1.161 & 0.427 & 1.316 \\
\hline Error (non-deflated) - (Last forecast) & 2.460 & 13.117 & 2.560 & 13.275 & 2.166 & 18.313 \\
\hline Brokerage house size & 79.724 & 89.655 & 53.781 & 67.617 & 87.895 & 85.747 \\
\hline Experience & 3.280 & 1.771 & 3.351 & 1.820 & 3.362 & 1.786 \\
\hline \# of firms covered & 12.142 & 6.907 & 8.261 & 4.056 & 8.711 & 3.959 \\
\hline \# of industries covered & 4.865 & 3.297 & 3.884 & 2.697 & 3.584 & 2.527 \\
\hline Forecast horizon (First forecast) & 163.619 & 54.298 & 173.888 & 57.453 & 171.348 & 57.853 \\
\hline Forecast horizon (Last forecast) & 101.904 & 49.598 & 86.132 & 49.969 & 87.767 & 51.740 \\
\hline Loss & 0.052 & 0.223 & 0.045 & 0.208 & 0.074 & 0.262 \\
\hline Firm size & 7.272 & 2.189 & 9.111 & 2.347 & 9.024 & 2.457 \\
\hline Absolute accruals & 0.041 & 0.038 & 0.037 & 0.037 & 0.045 & 0.037 \\
\hline
\end{tabular}

Panel A presents summary statistics for three groups of analysts. From Local GAAP to IFRS includes analysts, whose portfolios had firms following a single GAAP and after mandatory IFRS adoption all firms in their portfolio follow IFRS. From Multiple GAAP to IFRS includes analysts, whose portfolios had firms following different GAAP and after mandatory IFRS adoption all firms in their portfolio follow IFRS. The sample includes only mandatory IFRS adopters. A firm-analyst pair is included in the sample only if it appears both before and after mandatory IFRS adoption. First forecast uses the first forecast made by an analyst for a firm within 240 days (but not less than 30 days) from the end of the fiscal year. Last forecast uses the last forecast made by an analyst for a firm within 240 days (but not less than 30 days) from the end of the fiscal year. Error (deflated) is the absolute difference between actual earnings and individual forecast deflated by absolute actual earnings. Error (non-deflated) is the absolute difference between actual earnings and individual forecast. Brokerage house 
size is the number of analysts working for the brokerage house of the focal analyst. Experience is the number of years the analyst has been following a firm. \# of firms covered is the number of firms an analyst is covering in a year. \# of industries covered is the number of industries an analyst is covering in a year, based on the Fama-French industry classification. All other variable definitions are provided in Table 2. 
Panel B: Mandatory IFRS adoption and information environment: effect of accounting comparability

\begin{tabular}{|c|c|c|c|c|c|c|c|c|}
\hline \multirow{2}{*}{$\begin{array}{l}\text { Sample } \\
\text { Dependent variable }\end{array}$} & \multicolumn{4}{|c|}{ First forecast } & \multicolumn{4}{|c|}{ Last forecast } \\
\hline & \multirow{2}{*}{\multicolumn{2}{|c|}{ Error (deflated) }} & \multicolumn{2}{|c|}{ Error (non-deflated) } & \multicolumn{2}{|c|}{ Error (deflated) } & \multicolumn{2}{|c|}{ Error (non-deflated) } \\
\hline & & & \multicolumn{2}{|c|}{ (2) } & \multicolumn{2}{|c|}{ (3) } & \multicolumn{2}{|c|}{ (4) } \\
\hline Parameter & Estimate & $\mathrm{t}$ & Estimate & $\mathrm{t}$ & Estimate & $\mathrm{t}$ & Estimate & $\mathrm{t}$ \\
\hline Intercept & -0.6776 & -3.55 & -6.9735 & -3.26 & -0.7122 & -3.32 & -6.4635 & -2.92 \\
\hline Local GAAP to IFRS & 0.1174 & 1.67 & 1.7905 & 2.52 & 0.0580 & 0.84 & 1.9157 & 2.55 \\
\hline Multiple GAAP to IFRS & 0.1594 & 1.91 & 2.9558 & 2.59 & 0.1524 & 1.79 & 3.1900 & 2.64 \\
\hline Mandatory & 0.2127 & 3.69 & 2.8673 & 3.16 & 0.2535 & 3.37 & 3.2846 & 3.02 \\
\hline Local GAAP to IFRS * Mandatory & -0.1104 & -1.45 & -1.2665 & -2.09 & -0.0807 & -1.26 & -1.5294 & -2.25 \\
\hline Multiple GAAP to IFRS * Mandatory & -0.1798 & -1.92 & -3.2341 & -3.32 & -0.1713 & -1.74 & -3.4268 & -3.36 \\
\hline Forecast horizon & 0.0008 & 5.55 & 0.0035 & 2.02 & 0.0005 & 2.37 & -0.0017 & -0.80 \\
\hline Brokerage house size & -0.0003 & -2.85 & -0.0044 & -2.27 & -0.0003 & -2.77 & -0.0046 & -2.30 \\
\hline Experience & 0.0003 & 0.03 & -0.0056 & -0.04 & 0.0023 & 0.31 & -0.0245 & -0.17 \\
\hline \# of firms covered & 0.0010 & 0.39 & -0.0945 & -1.73 & 0.0001 & 0.05 & -0.1123 & -1.92 \\
\hline \# of industries covered & -0.0033 & -0.56 & 0.1832 & 2.00 & -0.0026 & -0.52 & 0.1898 & 1.97 \\
\hline Loss & 1.2160 & 9.48 & 3.8639 & 3.30 & 0.9349 & 8.67 & 3.6152 & 2.91 \\
\hline Firm size & -0.0027 & -0.27 & 0.3140 & 1.90 & 0.0059 & 0.60 & 0.3185 & 1.86 \\
\hline Absolute accruals & -0.2979 & -0.66 & 6.6745 & 0.90 & -0.0985 & -0.24 & 7.4445 & 0.98 \\
\hline Industry-year benchmark & 0.8273 & 5.00 & 0.0191 & 1.42 & 1.0935 & 4.78 & 0.0231 & 1.41 \\
\hline Country-year benchmark & 0.8573 & 4.52 & 1.3058 & 4.92 & 0.9431 & 3.85 & 1.4098 & 4.48 \\
\hline Adj R-squared & $11.2 \%$ & & $13.8 \%$ & & $9.8 \%$ & & $12.6 \%$ & \\
\hline $\mathrm{N}$ & 20,56 & & 20,564 & & 20,564 & & 20,564 & \\
\hline
\end{tabular}

Panel B presents OLS specifications testing the effect of mandatory IFRS adoption on forecast errors for three groups of analysts. From Local GAAP to IFRS

includes analysts, whose portfolios had firms following a single GAAP and after mandatory IFRS adoption all firms in their portfolio follow IFRS. From Multiple GAAP to IFRS includes analysts, whose portfolios had firms following different GAAP and after mandatory IFRS adoption all firms in their portfolio follow IFRS. From Local to Multiple GAAP includes analysts, whose portfolios had firms following a single GAAP and after mandatory IFRS adoption some firms in their portfolio follow IFRS and other firms Local or U.S. GAAP (omitted group). The sample includes only mandatory IFRS adopters. A firm-analyst pair is included in the sample only if it appears both before and after mandatory IFRS adoption. First forecast uses the first forecast made by an analyst for a firm 
within 240 days (but not less than 30 days) from the end of the fiscal year. Last forecast uses the last forecast made by an analyst for a firm within 240 days (but not less than 30 days) from the end of the fiscal year. Error (deflated) is the absolute difference between actual earnings and individual forecast deflated by absolute actual earnings. Error (non-deflated) is the absolute difference between actual earnings and individual forecast. Brokerage house size is the number of analysts working for the brokerage house of the focal analyst. Experience is the number of years the analyst has been following a firm. \# of firms covered is the number of firms an analyst is covering in a year. \# of industries covered is the number of industries an analyst is covering in a year, based on the Fama-French industry classification. Loss is an indicator variable if a firm is reporting negative net income. Industry-year benchmark is the average level of the dependent variable by year for each of the 49 Fama-French (1996) industries. Country-year benchmark is the average level of the dependent variable by year for each country. All other variable definitions are provided in Table 2. Standard errors are robust to heteroscedasticity and clustered at the firm level. 
TABLE 8

Panel A: Summary statistics by firm classification for analyst portfolios that change from Multiple GAAP to IFRS

\begin{tabular}{|c|c|c|c|c|}
\hline Analyst group & \multicolumn{4}{|c|}{ From Multiple GAAP to IFRS } \\
\hline \# of observations & \multicolumn{4}{|c|}{14147} \\
\hline \# of unique firms & \multicolumn{4}{|c|}{1064} \\
\hline \# of unique analysts & \multicolumn{4}{|c|}{776} \\
\hline Statistic & \multicolumn{4}{|c|}{ STD } \\
\hline Brokerage house size & \multicolumn{4}{|c|}{83.65} \\
\hline Experience & \multicolumn{2}{|r|}{3.35} & \multicolumn{2}{|l|}{1.78} \\
\hline \# of firms covered & \multicolumn{2}{|r|}{8.68} & \multicolumn{2}{|l|}{4.04} \\
\hline \# of industries covered & \multicolumn{2}{|r|}{3.66} & \multicolumn{2}{|l|}{2.50} \\
\hline Firm group & \multicolumn{2}{|c|}{ Mandatory adopters } & \multicolumn{2}{|c|}{ Voluntary adopters } \\
\hline \# of observations & \multicolumn{2}{|c|}{9538} & \multicolumn{2}{|c|}{4609} \\
\hline \# of unique firms & \multicolumn{2}{|c|}{719} & \multicolumn{2}{|c|}{345} \\
\hline Statistic & Mean & STD & Mean & STD \\
\hline Error (deflated) -(First forecast) & 0.495 & 1.389 & 0.431 & 1.054 \\
\hline Error (non-deflated) - (First forecast) & 2.272 & 18.111 & 2.345 & 22.340 \\
\hline Error (deflated) - (Last forecast) & 0.427 & 1.316 & 0.345 & 0.942 \\
\hline Error (non-deflated) - (Last forecast) & 2.166 & 18.313 & 1.849 & 18.594 \\
\hline Forecast horizon (First forecast) & 171.348 & 57.853 & 169.576 & 58.359 \\
\hline Forecast horizon (Last forecast) & 87.768 & 51.748 & 86.206 & 53.001 \\
\hline Loss & 0.074 & 0.262 & 0.069 & 0.254 \\
\hline Firm size & 9.024 & 2.457 & 8.825 & 2.089 \\
\hline Absolute accruals & 0.045 & 0.037 & 0.043 & 0.028 \\
\hline
\end{tabular}

Panel A presents summary statistics. From Multiple GAAP to IFRS includes analysts, whose portfolios had firms

following different GAAP and after mandatory IFRS adoption all firms in their portfolio follow IFRS. The sample includes voluntary and mandatory IFRS adopters. A firm-analyst pair is included in the sample only if it appears both before and after mandatory IFRS adoption. First forecast uses the first forecast made by an analyst for a firm within 240 days (but not less than 30 days) from the end of the fiscal year. Last forecast uses the last forecast made by an analyst for a firm within 240 days (but not less than 30 days) from the end of the fiscal year. Error (deflated) is the absolute difference between actual earnings and individual forecast deflated by absolute actual earnings. Error (non-deflated) is the absolute difference between actual earnings and individual forecast. Brokerage house size is the number of analysts working for the brokerage house of the focal analyst. Experience is the number of years the analyst has been following a firm. \# of firms covered is the number of firms an analyst is covering in a year. \# of industries covered is the number of industries an analyst is covering in a year, based on the Fama-French industry classification. All other variable definitions are provided in Table 2. 
Panel B: Mandatory IFRS adoption and information environment: information effect

\begin{tabular}{|c|c|c|c|c|c|c|c|c|}
\hline \multirow{2}{*}{$\begin{array}{l}\text { Sample } \\
\text { Dependent variable }\end{array}$} & \multicolumn{4}{|c|}{ First forecast } & \multicolumn{4}{|c|}{ Last forecast } \\
\hline & \multirow{2}{*}{\multicolumn{2}{|c|}{$\frac{\begin{array}{c}\text { Error } \\
\text { (deflated) }\end{array}}{(1)}$}} & \multirow{2}{*}{\multicolumn{2}{|c|}{$\begin{array}{c}\begin{array}{c}\text { Error } \\
\text { (non-deflated) }\end{array} \\
(2)\end{array}$}} & \multirow{2}{*}{\multicolumn{2}{|c|}{$\begin{array}{c}\begin{array}{c}\text { Error } \\
\text { (deflated) }\end{array} \\
(3)\end{array}$}} & \multirow{2}{*}{\multicolumn{2}{|c|}{$\begin{array}{c}\begin{array}{c}\text { Error } \\
\text { (non-deflated) }\end{array} \\
(4)\end{array}$}} \\
\hline & & & & & & & & \\
\hline Parameter & Estimate & $\mathrm{t}$ & Estimate & $\mathrm{t}$ & Estimate & $\mathrm{t}$ & Estimate & $\mathrm{t}$ \\
\hline Intercept & -0.3912 & -1.61 & -3.4213 & -1.41 & -0.5183 & -1.89 & -3.1698 & -1.35 \\
\hline Mandatory IFRS & 0.1916 & 2.02 & 1.7946 & 1.83 & 0.1874 & 2.08 & 1.9063 & 2.04 \\
\hline Mandatory & 0.1791 & 2.52 & 1.0633 & 1.86 & 0.2352 & 2.72 & 0.9659 & 1.58 \\
\hline Mandatory IFRS * Mandatory & -0.2079 & -2.00 & -1.5136 & -1.92 & -0.1912 & -1.98 & -1.3139 & -1.74 \\
\hline Forecast horizon & 0.0006 & 3.47 & 0.0022 & 1.11 & 0.0004 & 2.07 & 0.0036 & 1.16 \\
\hline Brokerage house size & -0.0004 & -2.51 & -0.0040 & -1.41 & -0.0004 & -3.05 & -0.0040 & -1.48 \\
\hline Experience & 0.0103 & 0.94 & -0.0838 & -0.43 & 0.0119 & 1.17 & -0.1079 & -0.51 \\
\hline \# of firms covered & -0.0006 & -0.14 & 0.0096 & 0.21 & -0.0011 & -0.28 & -0.0095 & -0.27 \\
\hline \# of industries covered & -0.0018 & -0.21 & -0.0263 & -0.57 & -0.0041 & -0.57 & -0.0133 & -0.27 \\
\hline Loss & 1.0731 & 8.32 & 2.2888 & 2.27 & 0.7142 & 6.83 & 1.7080 & 1.70 \\
\hline Firm size & -0.0160 & -1.34 & 0.1886 & 0.81 & -0.0095 & -0.86 & 0.1515 & 0.64 \\
\hline Absolute accruals & -0.3251 & -0.51 & 10.6378 & 0.75 & 0.2705 & 0.45 & 10.1576 & 0.76 \\
\hline Industry-year benchmark & 0.3986 & 2.84 & -0.0039 & -0.19 & 0.6357 & 3.31 & 0.0105 & 0.45 \\
\hline Country-year benchmark & 0.9893 & 3.82 & 1.0461 & 2.87 & 1.1755 & 3.07 & 1.1003 & 3.50 \\
\hline Adj R-squared & $10.4 \%$ & & $26.8 \%$ & & $8.3 \%$ & & $23.5 \%$ & \\
\hline $\mathrm{N}$ & 14,147 & & 14,147 & & 14,147 & & 14,147 & \\
\hline
\end{tabular}

Panel B presents OLS specifications testing the effect of mandatory IFRS adoption on forecast errors for two groups of firms. From Multiple GAAP to IFRS includes analysts, whose portfolios had firms following different GAAP and after mandatory IFRS adoption all firms in their portfolio follow IFRS. The sample includes only voluntary and mandatory IFRS adopters. A firm-analyst pair is included in the sample only if it appears both before and after mandatory IFRS adoption. Error (deflated) is the absolute difference between actual earnings and individual forecast deflated by absolute actual earnings. First forecast uses the first forecast made by an analyst for a firm within 240 days (but not less than 30 days) from the end of the fiscal year. Last forecast uses the last forecast made by an analyst for a firm within 240 days (but not less than 30 days) from the end of the fiscal year. Error (non-deflated) is the absolute difference between actual earnings and individual forecast. Forecast horizon is the number of days between consensus forecast and fiscal year end. Brokerage house size is the number of analysts working for the brokerage house of the focal analyst. Experience is the number of years the analyst has been following a firm. \# of firms covered is the number of firms an analyst is covering in a year. \# of industries covered is the number of industries an analyst is covering in a year, based on the Fama-French industry classification. Industry-year benchmark is the average level of the dependent variable by year for each 
of the 49 Fama-French (1996) industries. Country-year benchmark is the average level of the dependent variable by year for each country. All other variable definitions are provided in Table 2. Standard errors are robust to heteroscedasticity and clustered at the firm level. 
TABLE 9

Panel A: Effect of mandatory IFRS adoption on forecast errors and earnings management

\begin{tabular}{lrrrr}
\hline Dependent variable & \multicolumn{3}{c}{ Error (deflated) } \\
\hline Parameter & Estimate & \multicolumn{1}{c}{ t } & Estimate & $\mathrm{t}$ \\
\hline Intercept & -0.4520 & -5.02 & -0.4526 & -5.03 \\
Mandatory & 0.0070 & 0.98 & 0.0069 & 0.96 \\
Voluntary IFRS * Mandatory & $\mathbf{- 0 . 0 3 8 4}$ & $\mathbf{- 1 . 4 4}$ & $\mathbf{- 0 . 0 1 6 1}$ & $\mathbf{- 0 . 6 9}$ \\
Mandatory IFRS * Mandatory & $\mathbf{- 0 . 0 4 7 4}$ & $\mathbf{- 3 . 7 0}$ & $\mathbf{- 0 . 0 3 9 2}$ & $\mathbf{- 3 . 1 6}$ \\
Absolute accruals & -0.2799 & -6.19 & -0.2810 & -6.73 \\
Voluntary IFRS * Mandatory*Absolute accruals & $\mathbf{- 0 . 0 3 7 3}$ & $\mathbf{- 0 . 1 1}$ & & \\
Mandatory IFRS * Mandatory*Absolute accruals & $\mathbf{0 . 0 0 0 1}$ & $\mathbf{0 . 0 0}$ & & \\
CF forecasts & & & 0.0020 & 0.63 \\
Voluntary IFRS * Mandatory*CF forecasts & & & $\mathbf{- 0 . 0 2 4 0}$ & $\mathbf{- 2 . 0 9}$ \\
Mandatory IFRS * Mandatory*CF forecasts & & & $-\mathbf{0 . 0 0 7 3}$ & $\mathbf{- 1 . 1 7}$ \\
U.S. GAAP & 0.0680 & 13.44 & 0.0693 & 13.16 \\
Analyst coverage & -0.0010 & -4.17 & -0.0010 & -4.49 \\
Firm size & 0.0064 & 11.38 & 0.0064 & 11.46 \\
Loss & 0.2997 & 26.95 & 0.3000 & 26.97 \\
Forecast horizon & 0.0023 & 2.03 & 0.0023 & 2.02 \\
ADR & -0.0174 & -5.57 & -0.0177 & -5.65 \\
Industry-year benchmark & 0.1064 & 3.93 & 0.1058 & 3.91 \\
Country-year benchmark & 0.4542 & 21.12 & 0.4552 & 21.18 \\
Firm effects & Yes & & Yes & \\
Adj R-squared & $38.8 \%$ & & $38.8 \%$ & \\
N & 47,209 & & 47,209 & \\
\hline
\end{tabular}

This table presents OLS specifications testing the effect of mandatory IFRS adoption on forecast errors conditional on earnings management variables. Dependent variable is Error (deflated), which is the absolute difference between consensus forecast and actual earnings, divided by absolute actual earnings. Voluntary IFRS is an indicator variable for a firm that adopted IFRS before it was mandated in its country. Mandatory IFRS is an indicator variable that takes the value of one for a firm that adopts IFRS when its country mandated IFRS. Mandatory is an indicator variable that takes the value of one for periods on or after 2005 (2003 for Singapore). CF forecasts is the number of analysts that forecast cash flow per share divided by the number of analyst that forecast earnings per share. U.S. GAAP is an indicator variable that takes the value of one if a firm reports under U.S. GAAP. Industry-year benchmark is the average level of the dependent variable by year for each of the 49 Fama-French (1996) industries. Country-year benchmark is the average level of the dependent variable by year 
for each country. All other variable definitions are provided in Table 2. Standard errors are robust to heteroscedasticity and clustered at the firm and year level. 
TABLE 9

Panel B: Effect of mandatory IFRS adoption on the probability of meeting or beating analyst forecasts.

\begin{tabular}{|c|c|c|c|c|c|c|c|c|}
\hline \multirow[t]{2}{*}{ Sample } & \multicolumn{4}{|c|}{ Mandatory adopters } & \multicolumn{4}{|c|}{ Mandatory adopters excl. UK } \\
\hline & \multicolumn{2}{|c|}{ (1) } & \multicolumn{2}{|c|}{ (2) } & \multicolumn{2}{|c|}{ (3) } & \multicolumn{2}{|c|}{ (4) } \\
\hline Dependent variable & & & & Error ( & eflated) & & & \\
\hline Parameter & Estimate & $\mathrm{p}$-value & Estimate & $\mathrm{p}$-value & Estimate & $\mathrm{p}$-value & Estimate & p-value \\
\hline Intercept & 4.3101 & 0.064 & 4.4395 & 0.026 & 4.6361 & 0.191 & 5.7823 & 0.059 \\
\hline Mandatory & -0.4728 & 0.011 & -0.4263 & 0.007 & -0.4833 & 0.054 & -0.4775 & 0.026 \\
\hline GAAP Difference & 0.0316 & 0.156 & 0.0386 & 0.048 & 0.0358 & 0.122 & 0.0422 & 0.044 \\
\hline GAAP Difference * Mandatory & -0.0458 & 0.126 & -0.0284 & 0.261 & -0.0486 & 0.114 & -0.0386 & 0.148 \\
\hline Absolute accruals & -3.5092 & 0.122 & -1.6658 & 0.376 & -4.9180 & 0.048 & -2.2782 & 0.239 \\
\hline U.S. GAAP & 1.3936 & 0.149 & 0.9621 & 0.331 & 0.6045 & 0.569 & 0.1245 & 0.909 \\
\hline Analyst coverage & 0.0601 & $<.0001$ & 0.0626 & $<.0001$ & 0.0398 & 0.004 & 0.0433 & 0.000 \\
\hline Firm size & -0.2521 & $<.0001$ & -0.2574 & $<.0001$ & -0.3011 & $<.0001$ & -0.3245 & $<.0001$ \\
\hline Loss & -0.5858 & 0.021 & -0.9536 & $<.0001$ & -0.4487 & 0.073 & -0.8386 & 0.000 \\
\hline Forecast horizon & -0.0615 & 0.029 & -0.0555 & 0.022 & -0.0494 & 0.257 & -0.0550 & 0.144 \\
\hline $\mathrm{ADR}$ & 0.0200 & 0.942 & 0.0210 & 0.924 & 0.5296 & 0.064 & 0.5678 & 0.012 \\
\hline Industry-year benchmark & 3.2784 & $<.0001$ & 3.6022 & $<.0001$ & 2.4881 & 0.012 & -2.9143 & 0.000 \\
\hline Country-year benchmark & 0.8596 & 0.215 & 0.8486 & 0.134 & -0.2004 & 0.761 & -0.2110 & 0.690 \\
\hline Firm effects & Yes & & Yes & & Yes & & Yes & \\
\hline Adj. R-squared & $4.07 \%$ & & $5.21 \%$ & & $6.67 \%$ & & $7.91 \%$ & \\
\hline $\mathrm{N}$ & 8,168 & & 8,168 & & 5,709 & & 5,709 & \\
\hline
\end{tabular}

This table presents a logistic specification testing the likelihood of meeting or beating analyst forecasts following mandatory adoption of IFRS. The dependent variable takes the value of one if the realized earnings are equal to or greater by one cent per share of the analyst's forecast (columns 1 and 3 ). As a sensitivity analysis we also present results where the dependent variable takes the value of one if realized earnings are equal to forecasted earnings or greater by at most three cents of the analyst's forecast (columns 2 and 4). Mandatory adopters includes all firms that are mandatory adopters of IFRS with available IFRS reconciliation and IBES data. Mandatory adopter's excl. UK includes all firms that are mandatory adopters of IFRS with available IFRS reconciliation and IBES 
data outside the United Kingdom. GAAP difference is the absolute difference between IFRS earnings and local GAAP earnings, as published in the reconciliation documents of first time adopters in 2005, divided by the absolute local GAAP earnings. U.S. GAAP is an indicator variable that takes the value of one if a firm reports under U.S. GAAP. Industry-year benchmark is the average level of the dependent variable by year for each of the 49 Fama-French (1996) industries. Country-year benchmark is the average level of the dependent variable by year for each country. All other variable definitions are provided in Table 2. Standard errors are robust to heteroscedasticity and clustered at the firm and year level. 